\title{
Imaging surveillance programs for women at high breast cancer risk in Europe: Are women from ethnic minority groups adequately included? (Review)
}

\author{
KAREN BELKIĆ ${ }^{1-3}$, MIRI COHEN ${ }^{4}$, BRIGITTE WILCZEK $^{5}$, SONIA ANDERSSON $^{1}$, \\ ANNE H. BERMAN ${ }^{1}$, MARCELA MÁRQUEZ ${ }^{1,6}$, VLADANA VUKOJEVIĆ ${ }^{1}$ and MIRIAM MINTS ${ }^{1}$ \\ ${ }^{1}$ The Karolinska Institute and Hospital, Departments of Oncology-Pathology, Women's and Children's Health \\ and of Clinical Neuroscience, Stockholm, Sweden; ${ }^{2}$ Claremont Graduate University, School of Community and \\ Global Health, Claremont, CA; ${ }^{3}$ University of Southern California School of Medicine, Institute for Prevention \\ Research, Los Angeles, CA, USA; ${ }^{4}$ University of Haifa, Faculty of Social Welfare and Health Sciences, \\ Haifa, Israel; ${ }^{5}$ Sankt Görans Hospital, Unilabs Department of Mammography, Stockholm, Sweden; \\ ${ }^{6}$ Autonomous University of Nuevo Leon, School of Medicine, Monterrey, NL, Mexico
}

Received April 29, 2015; Accepted June 2, 2015

DOI: $10.3892 /$ ijo.2015.3063

\begin{abstract}
Women from ethnic minority groups, including immigrants and refugees are reported to have low breast cancer (BC) screening rates. Active, culturally-sensitive outreach is vital for increasing participation of these women in $\mathrm{BC}$ screening programs. Women at high $\mathrm{BC}$ risk and who belong to an ethnic minority group are of special concern. Such women could benefit from ongoing trials aimed at optimizing screening strategies for early BC detection among those at increased $\mathrm{BC}$ risk. Considering the marked disparities in BC survival in Europe and its enormous and dynamic ethnic diversity, these issues are extremely timely for Europe. We systematically reviewed the literature concerning European surveillance studies that had imaging in the protocol and that targeted women at high $\mathrm{BC}$ risk. The aim of the present review was thereby to assess the likelihood that women at high BC risk from minority ethnic groups were adequately included in these surveillance programs. Twenty-seven research groups
\end{abstract}

Correspondence to: Professor Sonia Andersson, Department of Women's and Children's Health, Division of Obstetrics and Gynecology, Karolinska Institutet, Elevhemmet H2:00, Karolinska University Hospital Solna, 17176 Stockholm, Sweden

E-mail: sonia.andersson@ki.se

Abbreviations: $\mathrm{CBE}$, clinical breast examination; $\mathrm{CE}$, contrast enhanced; MARIBS, magnetic resonance imaging for breast cancer screening study (UK); MRI, magnetic resonance imaging; MRISC, multicenter MRI screening study (The Netherlands); PIMMS, psychological impact of mammography screening in women with family history of breast cancer (UK); STIC IRM, magnetic resonance imaging study group (France)

Key words: breast cancer, early detection, imaging surveillance, BRCA mutations, cultural sensitivity, ethnicity in Europe reported on their imaging surveillance programs for women at increased $\mathrm{BC}$ risk. The benefit of strategies such as inclusion of magnetic resonance imaging and/or more intensive screening was clearly documented for the participating women at increased BC risk. However, none of the reports indicated that sufficient outreach was performed to ensure that women at increased $\mathrm{BC}$ risk from minority ethnic groups were adequately included in these surveillance programs. On the basis of this systematic review, we conclude that the specific screening needs of ethnic minority women at increased BC risk have not yet been met in Europe. Active, culturally-sensitive outreach is needed to identify minority women at increased $\mathrm{BC}$ risk and to facilitate their inclusion in on-going surveillance programs. It is anticipated that these efforts would be most effective if coordinated with the development of European-wide, population-based approaches to BC screening.

\section{Contents}

1. Breast cancer survival disparities, ethnicity and related issues for Europe

2. Search strategy for identifying European imaging surveillance studies targeting women at high breast cancer risk

3. Protocol for reviewing the identified surveillance studies

4. General description of the 27 identified European study centers

5. Benefits of imaging surveillance for women at high breast cancer risk as assessed in the 27 study centers

6. Recruitment of women into the programs and considerations of ethnicity and high risk, including testing for relevant gene mutations

7. Family history assessment, including reliance on national data registries 
8. Overall assessment of the likelihood of including women at high breast cancer risk and who belong to minority ethnic groups into the 27 study centers

9. Broader considerations of relevance for Europe based on the present analysis

10. Limitations and challenges of the present review

11. Suggested next steps

12. Conclusions

\section{Breast cancer survival disparities, ethnicity and related issues for Europe}

Breast cancer is the most commonly diagnosed malignancy and a leading cause of cancer deaths among women in Europe $(1,2)$. Survival after diagnosis of breast cancer varies markedly across Europe; this is attributed to differences in stage at diagnosis (3). Early breast cancer detection can be achieved through screening which, when followed by appropriate assessment and management, has been demonstrated to significantly reduce mortality from breast cancer $(4,5)$.

The importance of screening has been particularly emphasized for women with high breast cancer risk, for whom there is a greater likelihood of more aggressive tumors presenting at a younger age (6-8). Intensive screening using various imaging modalities is reportedly tolerated and preferred by women at high risk, compared to options such as prophylactic mastectomy $(9,10)$. Many investigations have focused upon finding the best strategies for screening surveillance of women with high breast cancer risk $(11,12)$. In the UK women at very high risk of familial breast cancer are being offered annual surveillance with magnetic resonance imaging from age 30 to 49 years and annual mammography from the age of 40-69 (13).

A critical challenge is to effectively identify women from the general population who are at high risk for breast cancer, so that they can benefit from these more intensive screening surveillance strategies. Breast cancer risk assessment models have been based upon family history, including age of disease onset. However, it has been reported that relying on family history can be tenuous, especially for identifying $B R C A 1 / 2$ mutation carriers (14-16).

Certain ethnic groups within Europe are recognized to have a high prevalence of $B R C A 1 / 2$ mutations; these include Ashkenazi Jewish, Icelandic and Inuit groups, inter alia $(5,17,18)$. Founder BRCA1/2 mutations (founders are fairly small groups of people who have been somewhat isolated over long periods of time, such that a mutation which would otherwise have been rare becomes relatively common within the population) have been identified for these groups, as well as for other European populations including, for example, Norwegians, Finns, Swedes, Dutch, Calabrians and Sardinians from Italy (19) as well as among Slavic people (20). In addition, founder $B R C A 1 / 2$ mutations have been detected for several other ethnic groups whose members have immigrated to Europe. Among these groups are Pakistanis, Malaysians, Hispanics from Colombia, Japanese, Chinese and Sephardic Jews from several Arab countries $(19,21)$. It has been suggested that testing for $B R C A 1 / 2$ should be considered for much less significant family history among founder populations (13), and that population screening for BRCA mutations may be an appropriate alternative for such populations (22). On the other hand, among ethnic groups in Europe with overall low breast cancer risk, the relative percentage of aggressive cancers appearing among young patients may be very high, as is reported among North African populations living in France (23).

It is also important to take into account small family size, 'limited family structure' (24) when assessing breast cancer risk, especially when there are few middle-aged or older female family members. Since the BRCA breast and ovarian cancer syndrome has an autosomal dominant inheritance, $\sim 50 \%$ of the mutation carriers will be male. Especially insofar as the number of female 1st and 2 nd degree relatives above age 45 is small, with a limited family structure, the likelihood of accurately predicting BRCA mutation carrier status in single cases of early-onset breast cancer may be substantially diminished (25-27).

Lower breast cancer screening rates and consequent late stage diagnosis have been frequently associated with ethnic minority groups. This is particularly the case for women who are economically deprived and/or immigrants or refugees (28-36). Women from ethnic minority groups who are at high breast cancer risk are thus of particular concern. A critical question is whether these women are adequately included in ongoing screening programs aimed at women with high breast cancer risk. Given Europe's enormous ethnic diversity and the influx of residents from the entire world, in addition to the marked disparities in breast cancer survival, these issues are extremely timely.

In our earlier review performed through 2008 (34), we identified breast cancer surveillance studies of high-risk women from fifteen European centers that had imaging in their protocols. Our focus therein was on the Jewish population as a high-risk group. Our conclusion at that time was that the imaging surveillance was beneficial, but that Jewish women and other ethnic minority groups at potentially high risk were unlikely to have been adequately included in these programs.

The aim of the present study is to systematically review the published literature from Europe, through the more recent period (end of 2014), on breast cancer surveillance studies that had imaging in the protocol and that targeted women at high-risk for breast cancer. Our research focus is broadened in the present study to assess the likelihood that women from diverse minority ethnic groups were adequately included in these surveillance programs. The overall purpose of this review is to identify ways of diminishing the disparities in breast cancer survival in Europe.

\section{Search strategy for identifying European imaging surveillance studies targeting women at high breast cancer risk}

We sought empirical studies based in Europe, which targeted women at high risk for breast cancer, and which had imaging as part of the surveillance protocol. The latter included more frequent mammography screening intervals, younger age of onset for mammography, use of magnetic resonance imaging (MRI) and/or ultrasound. Studies were excluded if only persons already diagnosed with breast cancer were examined or if imaging was only used for evaluating previously detected lesions. 
We began with Ovid Medline using the search terms as key words plus the 'explode' option. This was performed as follows: [(breast cancer) AND (high risk) AND \{(ultrasound) or (mammography) or (magnetic resonance imaging)\}]. Altogether, 1024 possibly eligible studies were identified. A PubMed search was then done, using the following strategy: [\{(surveillance) or (early detection) $\}$ and (high risk) and (breast cancer)]. This yielded another 260 potentially eligible studies. We also searched PubMed through the strategy: [\{(breast cancer)\} AND (high risk) AND \{(Europe) or (Scandinavia) or any of (42 European country names) $\}$ ], finding another 90 potentially eligible studies. These searches were performed through December 2014. The abstracts and/or full-text studies were then reviewed. Relevant cited studies were accessed for needed background information.

Altogether we identified 27 different European study centers that fulfilled the above-described criteria. One or more studies were found that reported empirical data about these surveillance programs. There was a total of 62 such studies (37-46,50-67,70-74,76-82,84-87,91-93, 95-96,99-102,106,107,110-112,120,121,123,126). In addition, another 30 studies provided background information about the Study Centers (47-49,68,69,75,83,88-90,94,97,98, $103-105,108,109,113-119,122,124,125)$.

\section{Protocol for reviewing the identified surveillance studies}

For each of the 27 surveillance programs, an independent review was performed by two investigators. Basic information was summarized, including the imaging modalities used, number of cases detected and benefit of the trial. The studies were scrutinized to ascertain how participants were recruited, as well as criteria for entry into the study. Next, the studies were examined to determine whether a) there was any note of ethnic minority groups at high risk for breast cancer, and if so, b) whether these groups were taken into account in the actual risk assessment and recruitment. Each reviewer also assessed whether the studies considered: c) the possibility of limited family structure and d) family members living outside the country.

On the basis of points a) through d) together with consideration of the entry criteria and recruitment procedure, each of the 27 study centers was given an overall assessment rating concerning the likelihood of adequately including minority ethnic women at high breast cancer risk in the study catchment area.

This overall assessment was scored as follows: 3, Active surveillance with a very high participation rate of the entire at-risk minority population in the catchment area; adequate account taken of eventual limited family structure and family living outside the country. 2, Systematic efforts were made to include at-risk minority populations, but the study center unlikely to have achieved sufficiently high coverage to do so. 1, Although not taken into account for recruitment, highrisk ethnicity and/or limited family structure and/or family members living outside the country were factors considered in the study design. 0 , No attention whatsoever to high-risk ethnicity nor to limited family structure nor to family members living outside the country. Recruitment procedure and entry criteria render it very unlikely that women at high breast cancer risk who are from ethnic minority groups were included in the program.

The scores were additive, such that each study was credited for all actions that could have increased the likelihood of adequately detecting and including women from minority ethnic groups at high breast cancer risk within the catchment area. Fractional scores to the 0.25 level were permitted. Insofar as the two reviewers could not arrive at consensus, a third served as arbiter. Arbitration was needed for two of the 27 study groups.

\section{General description of the 27 identified European study centers}

Table I summarizes the pertinent considerations about each of 27 study centers. The centers are sorted by country, and each was assigned an identification number for the purpose of our assessment.

We begin with the Netherlands where one of the largest prospective investigations was performed among 2157 women. This was the Dutch Multicenter MRI Screening Study (MRISC), denoted as Study Center \#1 (37-46). In the MRISC, biannual clinical breast exam (CBE), annual contrast enhanced (CE) MRI and mammography were performed in most cases. The other two Study Centers from the Netherlands $(50,51)$ also applied CBE, CE-MRI and mammography, and in Study Center \#2 (50) ultrasound was used in some cases.

Study Centers \#\#4-10 (52-76) from the UK used various combinations and schedules of mammography, CE-MRI and ultrasound and CBE. The UK Multicentre Study (MARIBS) and the subsequent Nightingale Study (Study Center \#4) (52-67) followed altogether 959 women at high risk for up to 7 years with annual CE-MRI and mammography. Study Center \#10 (77) from the UK examined women age 35-39 with elevated breast cancer risk who underwent surveillance via annual mammography.

From the German Study Centers (\#\#11-13) (78-85) CBE, CE-MRI, mammography and often ultrasound were also performed. The German Multicenter Study (\#11) (78) and the Bonn Center (\#12) (79-82) followed 413 and 629 women for up to 6 and up to 10 years, respectively.

The Italian Centers (\#\#14-16) (86-95) also used CBE, CE-MRI, mammography and ultrasound in various combinations. The Italian Multicenter Study (\#14) $(86,87)$ included 501 women enrolled between 2000 and 2007 and performed 1592 screening rounds. The Modena Study (\#15) (91-93) included 1325 women who were followed for up to 11 years.

There were two Polish Study Centers (\#\#17 and 18) (96-99). The Center from Szczecin (\#17) (96-98) provided the majority of 212 women at high breast cancer risk with mammography and in a few cases with MRI, and reported 18 months of follow-up. All 379 women included in the Krakow Center (\#18) (99) received MRI, after undergoing mammography and ultrasound that had shown no abnormalities.

The French Study Centers (\#\#19-21) (100-106) used combinations of MRI, mammography and ultrasound. The French Multicenter Study (STIC IRM) $(100,101)$ included 1561 women with a few months of reported follow-up. The Vienna Study Center (\#22) (107) included 327 women with up to 7 years of follow-up, using mammography, MRI and ultrasound. 


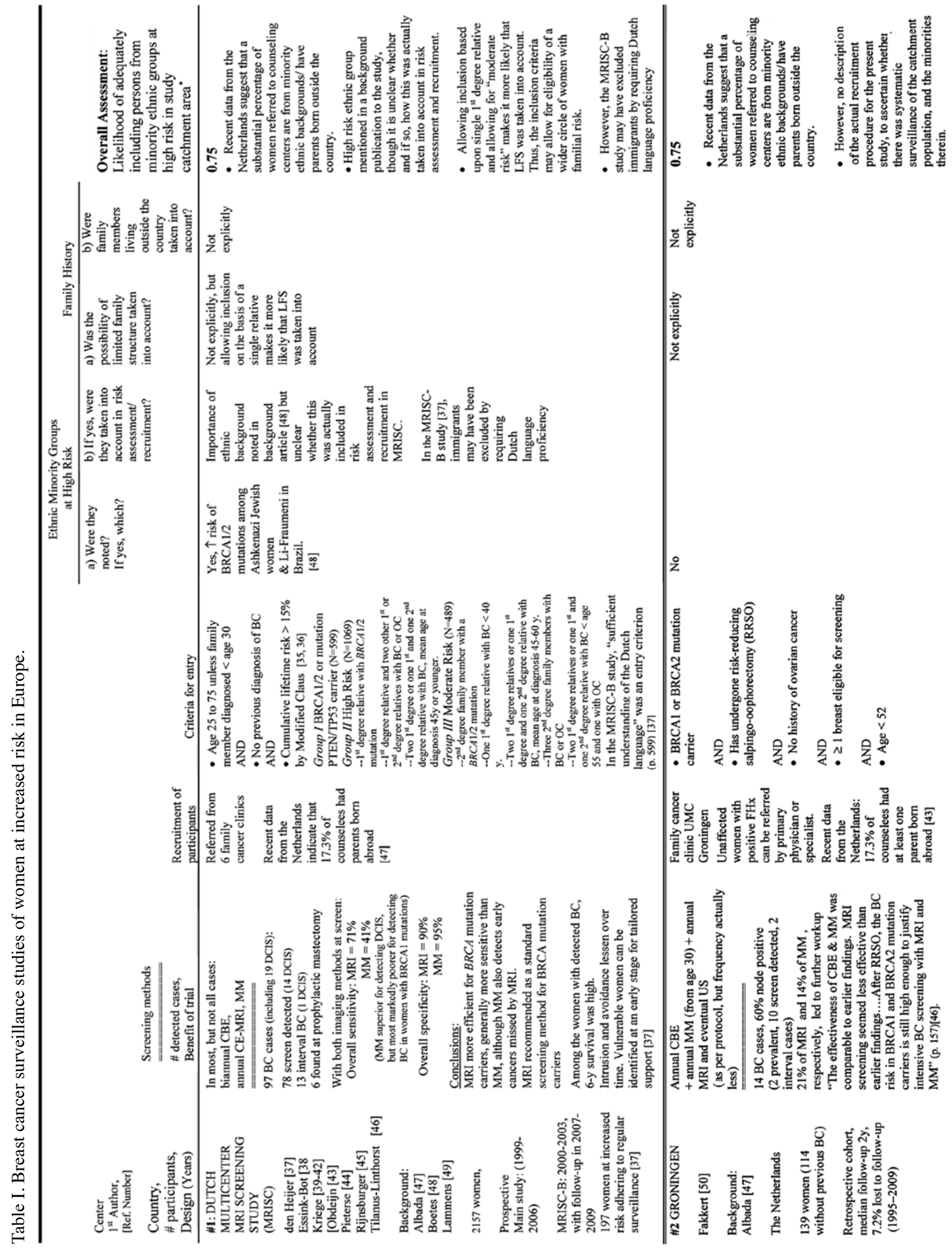



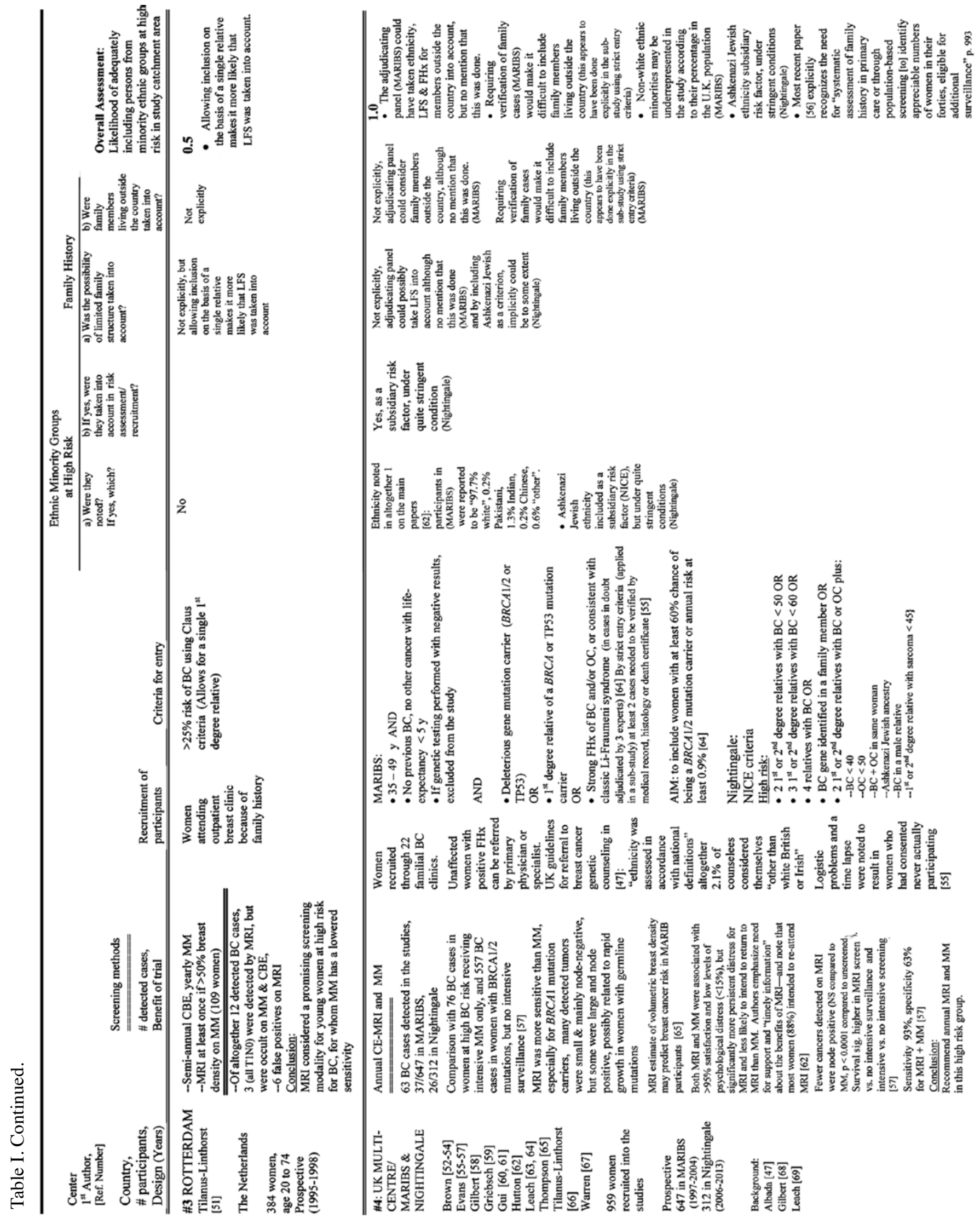

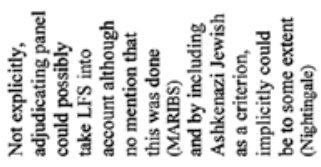

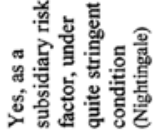

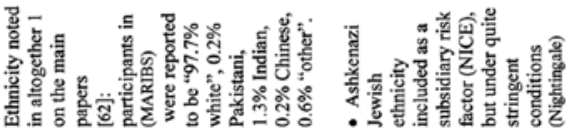
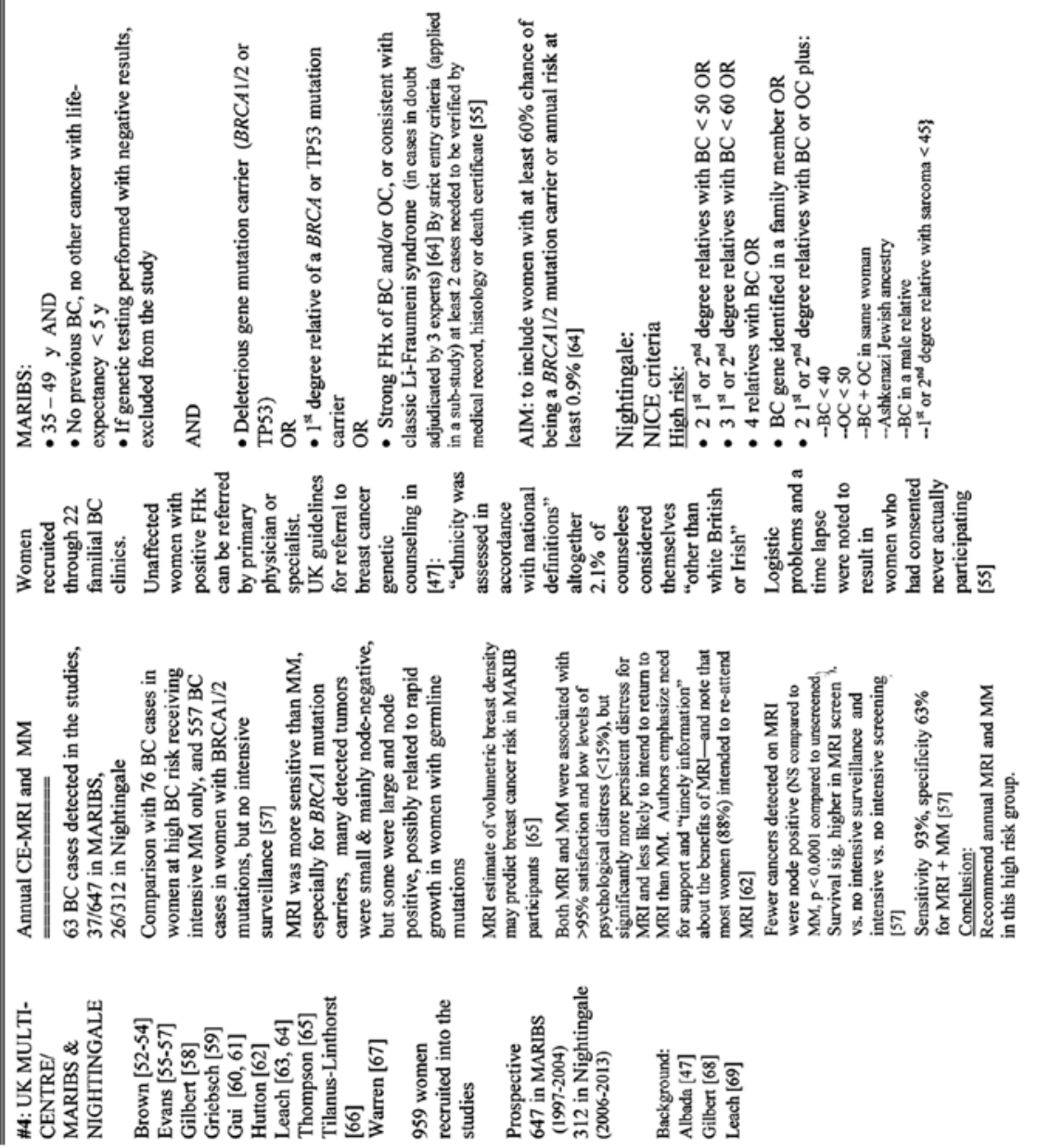


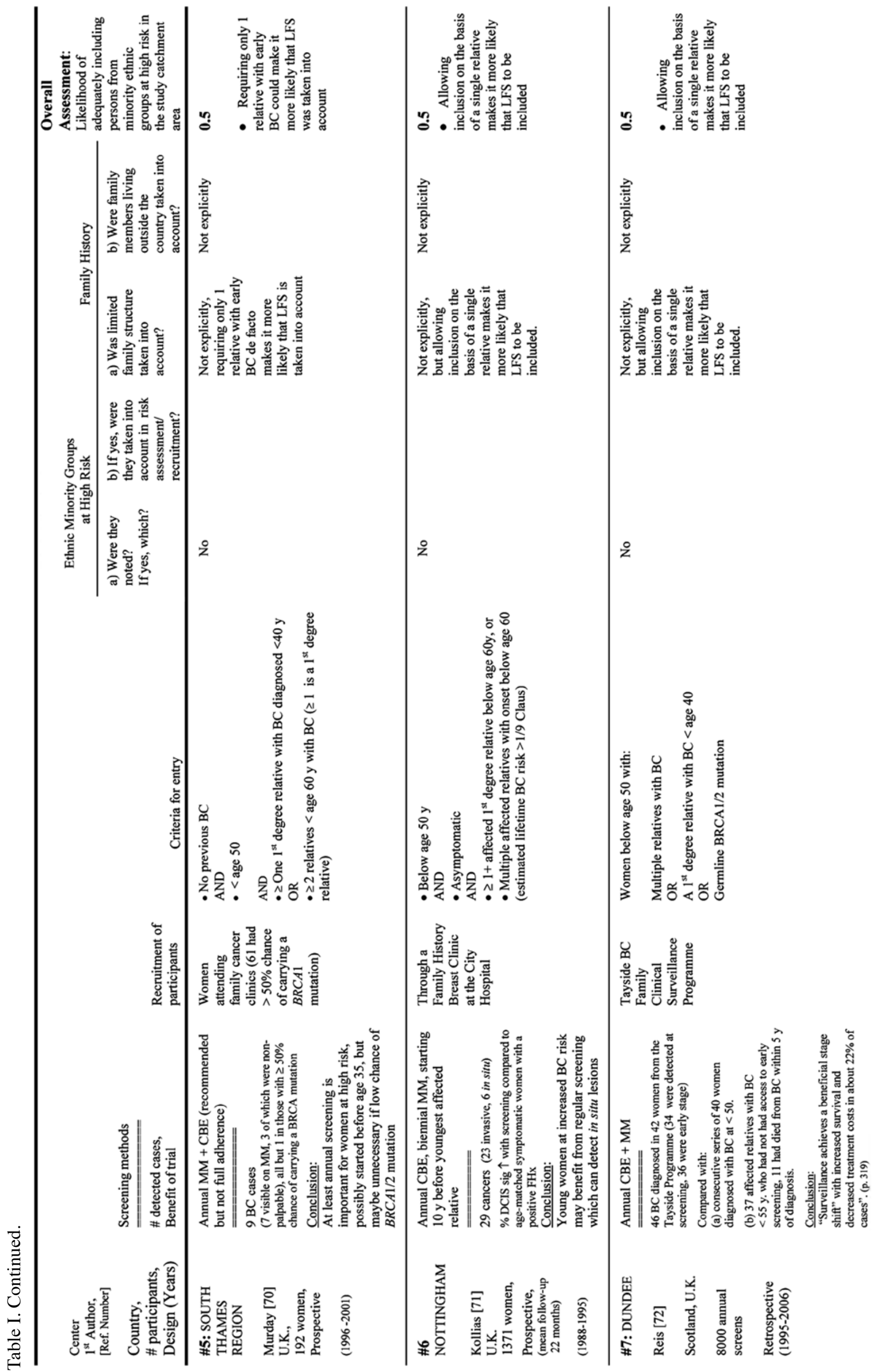




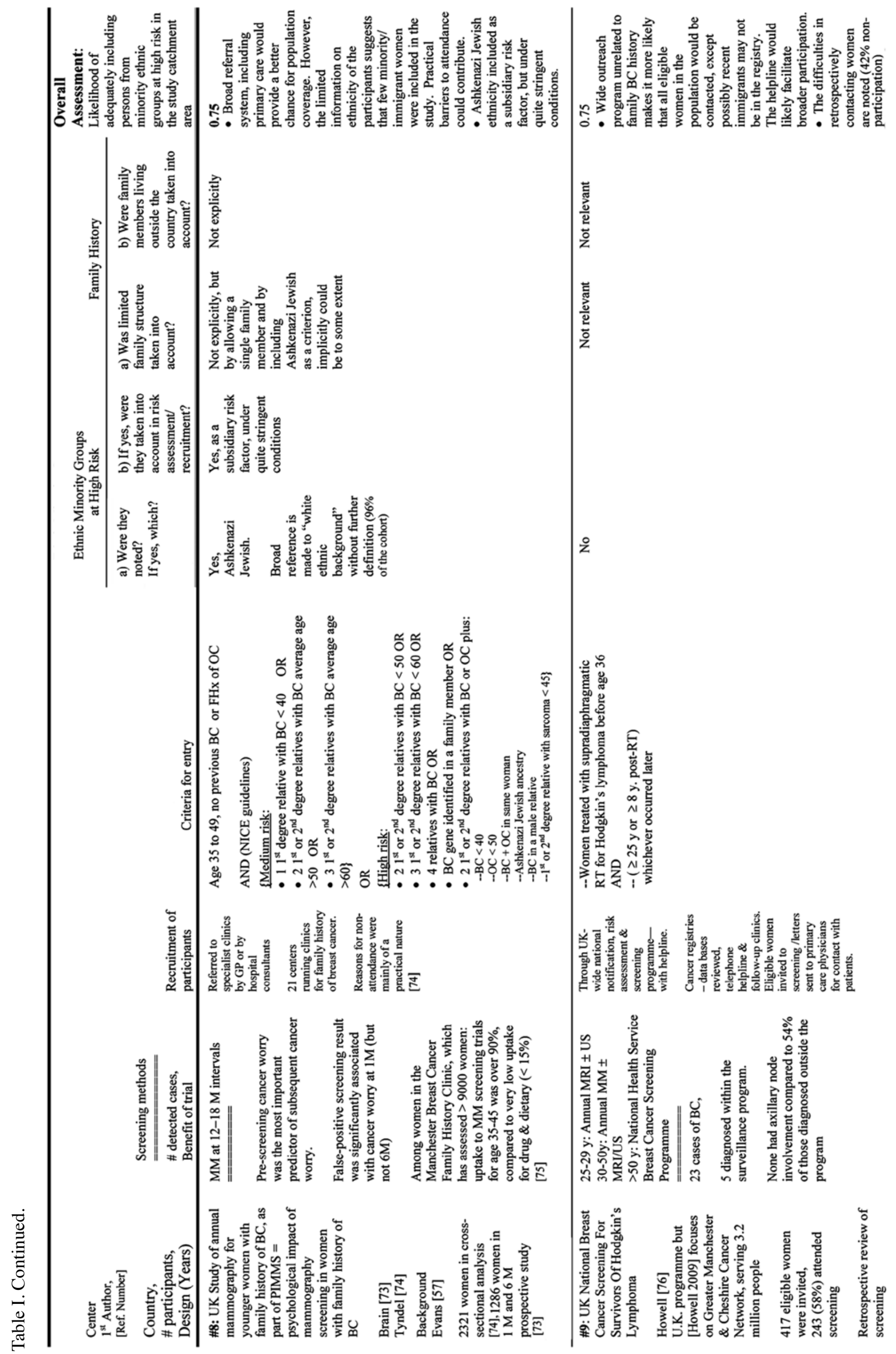




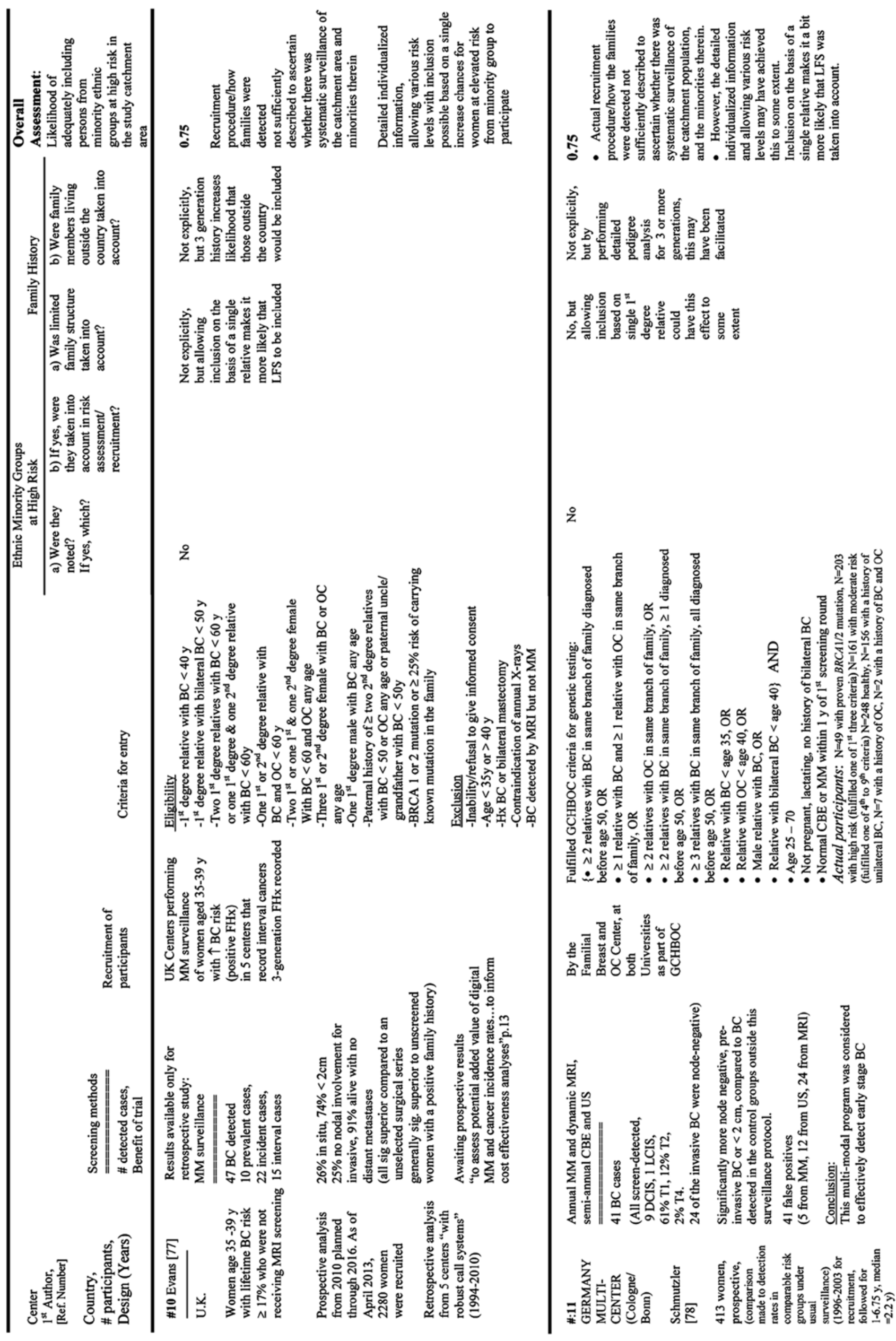




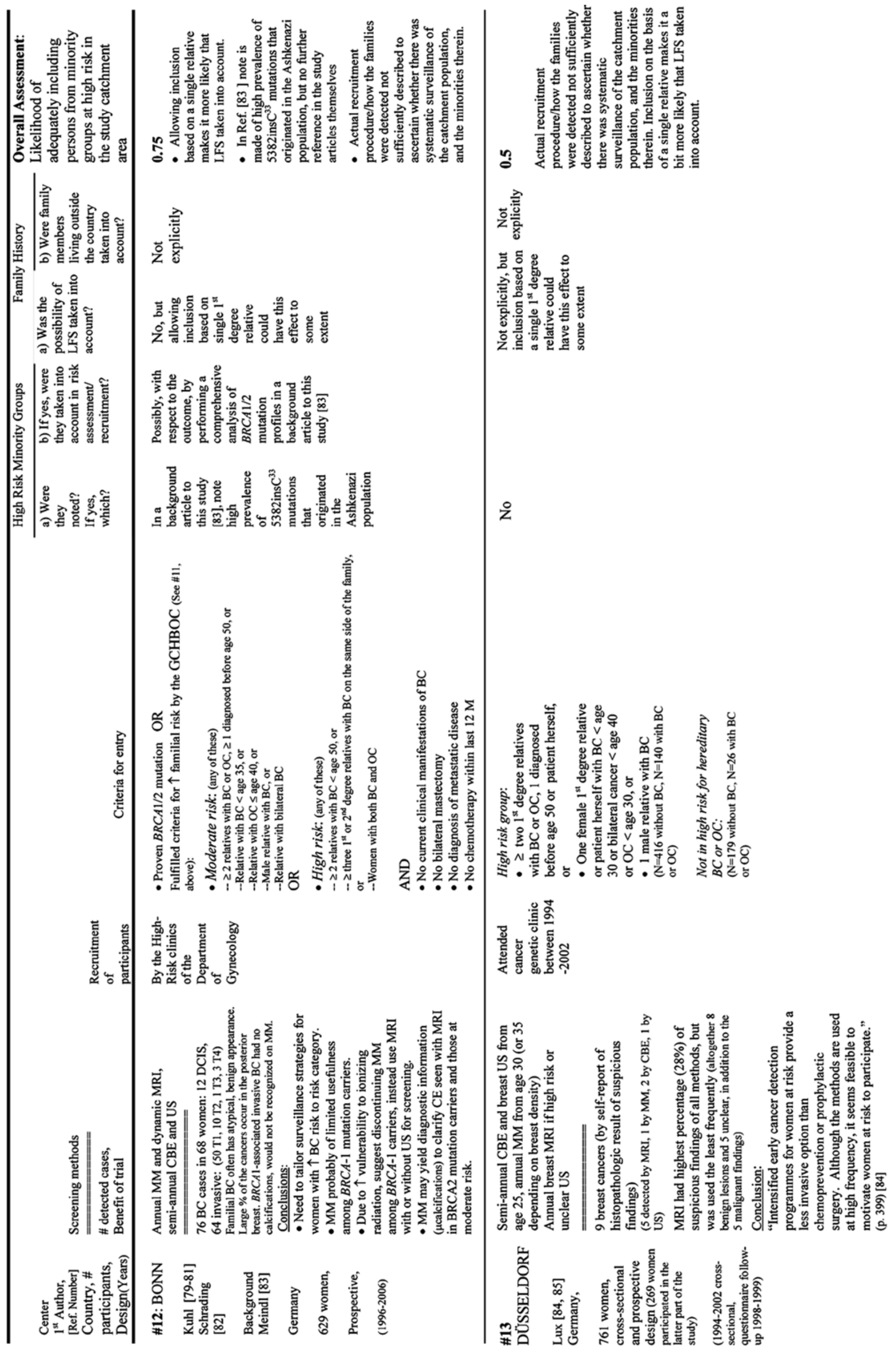




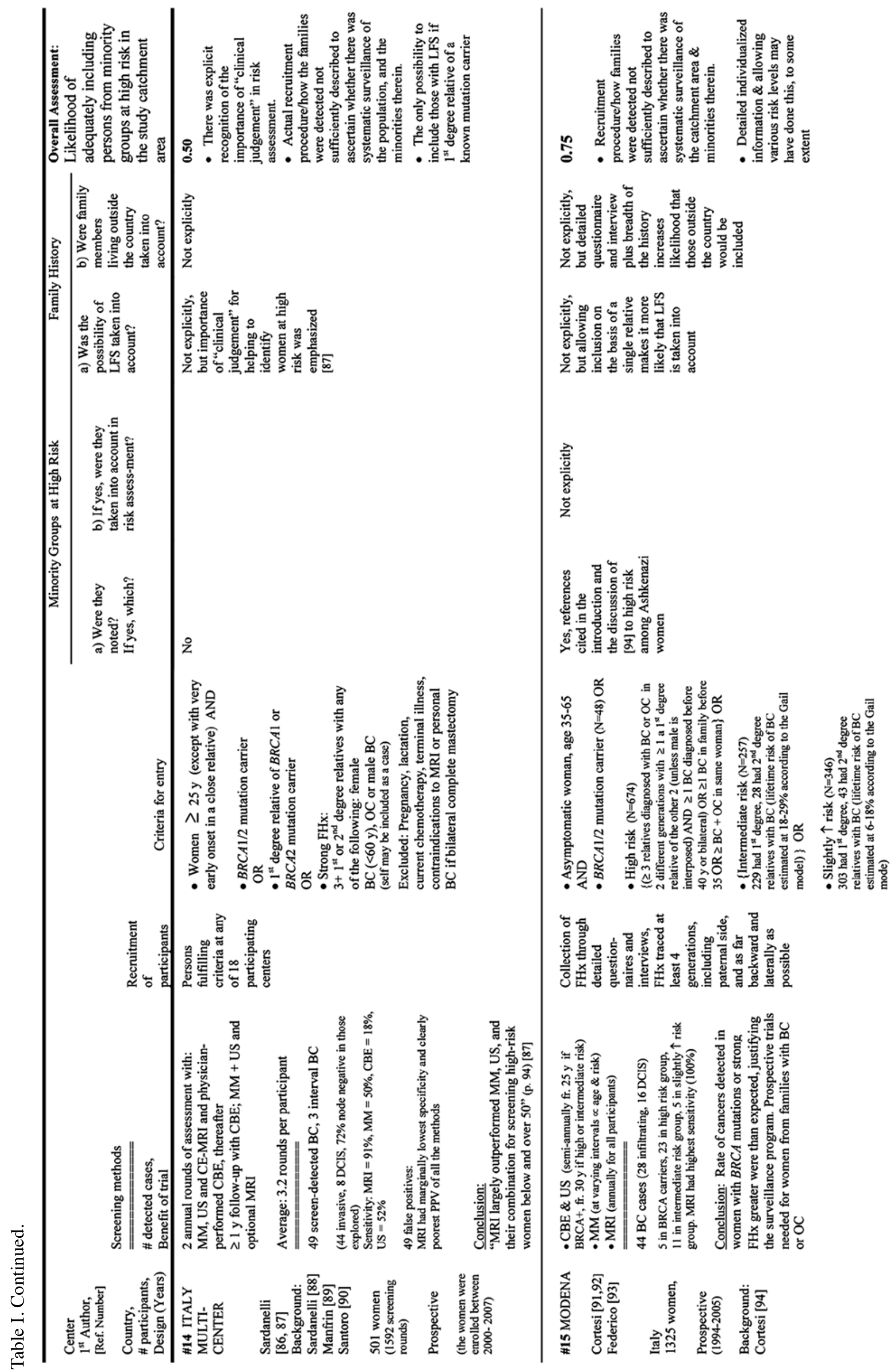




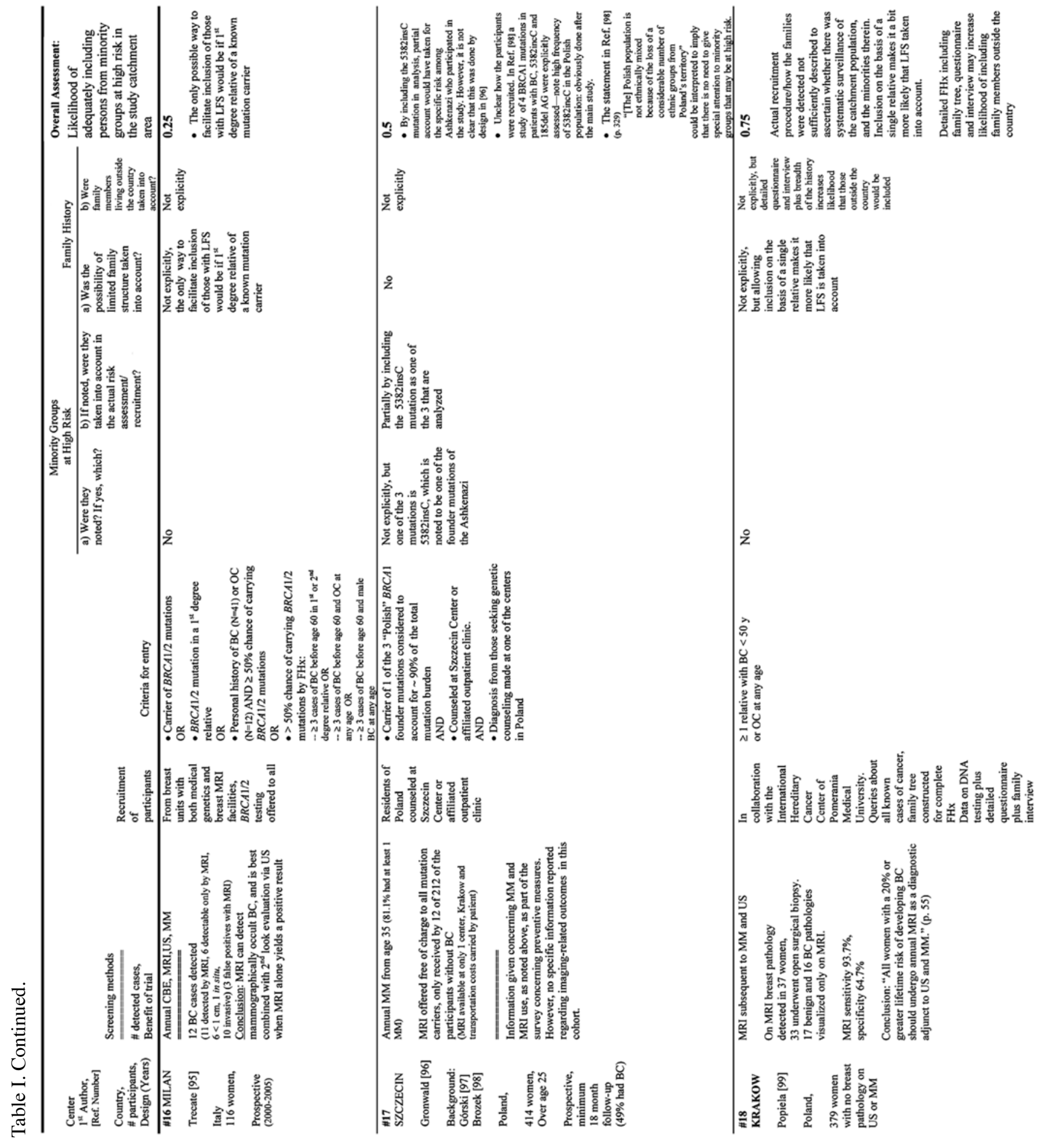




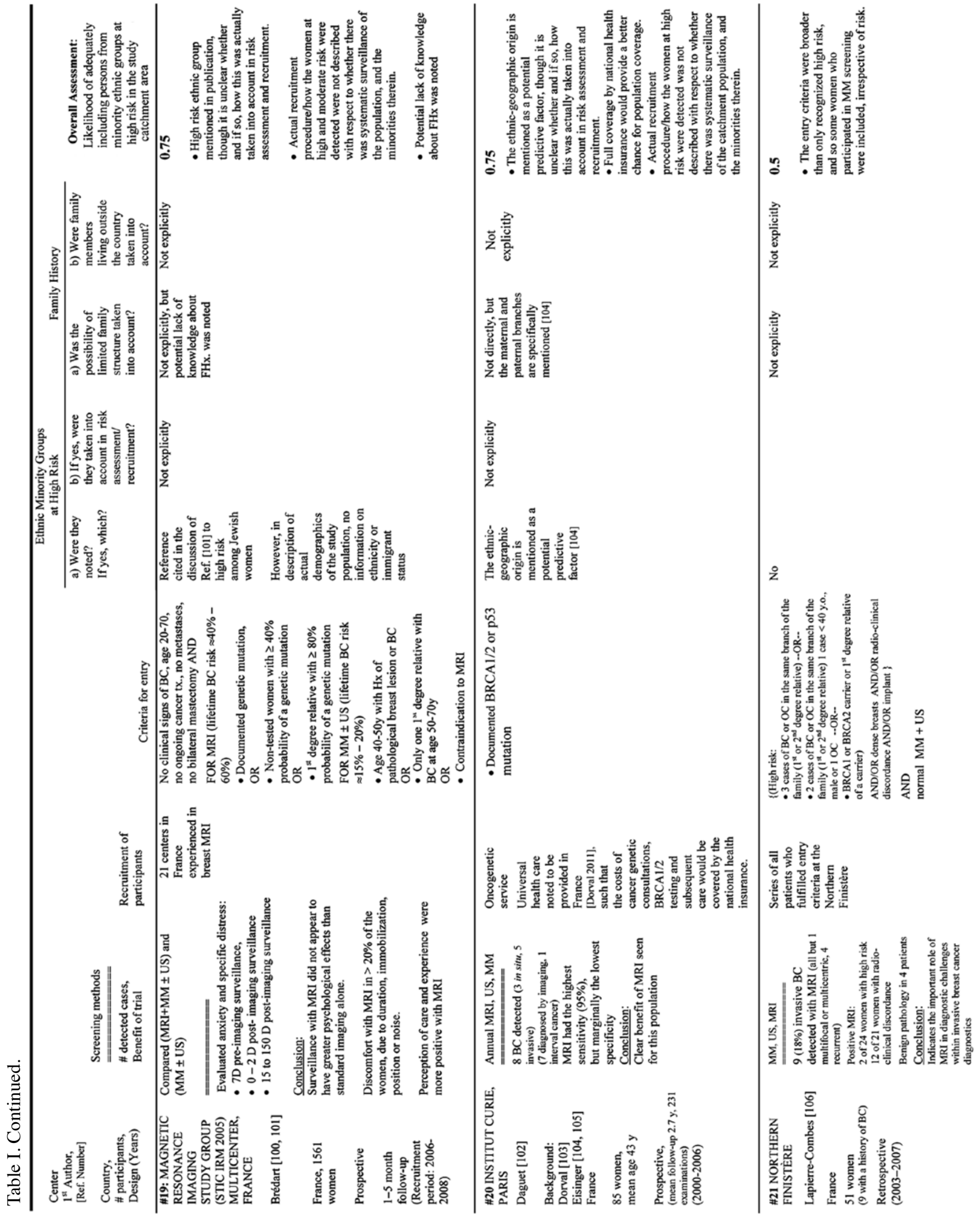




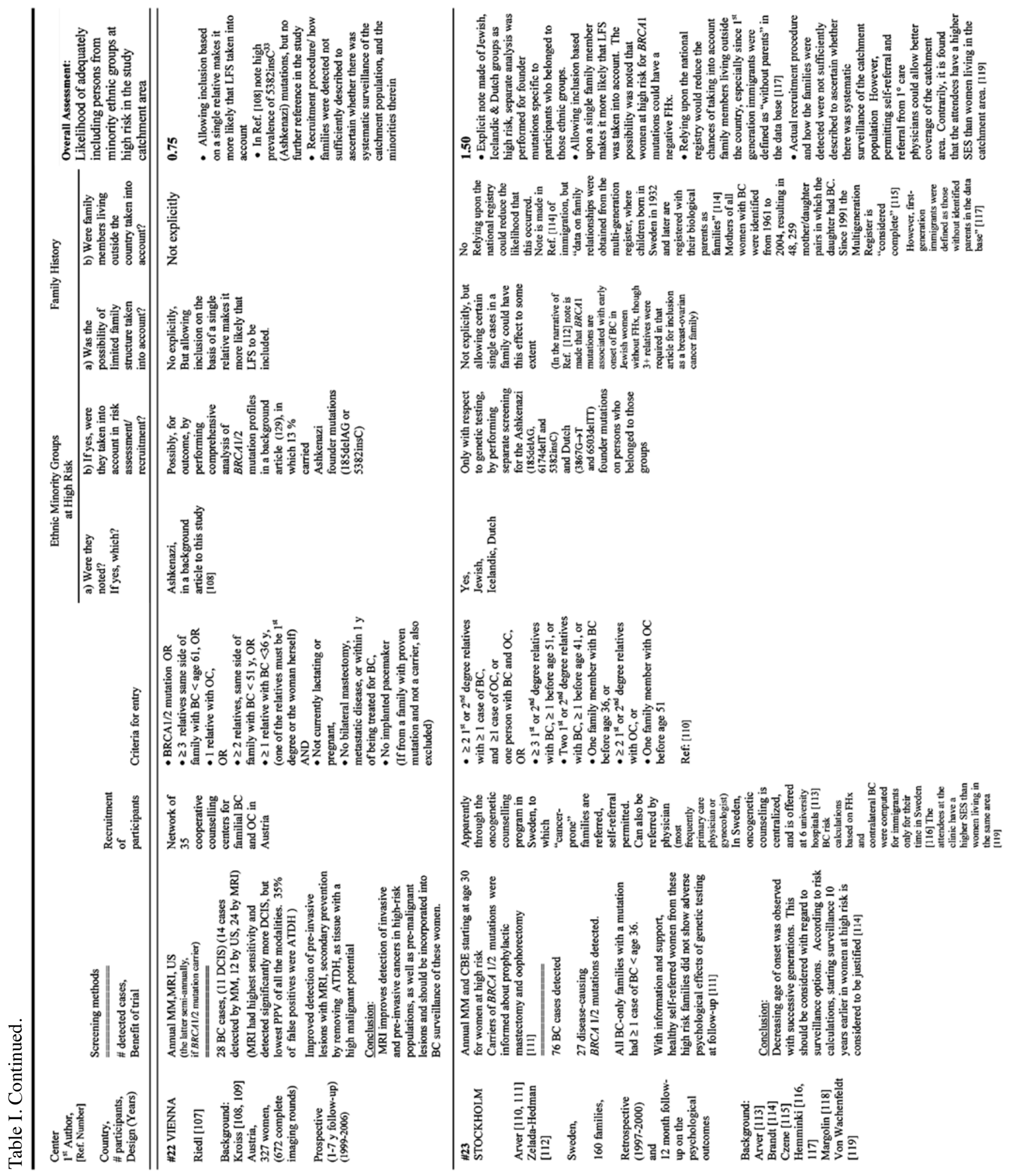




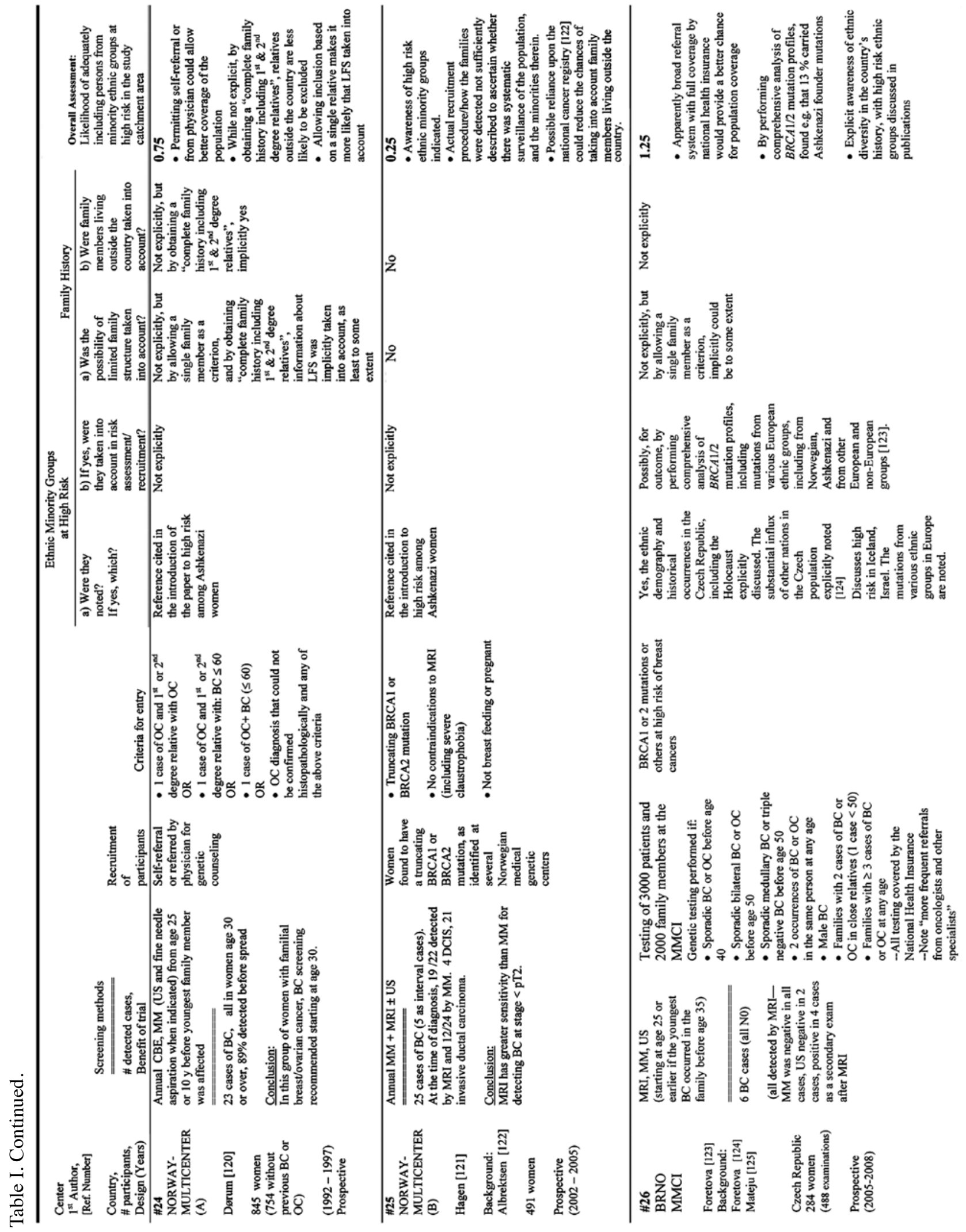




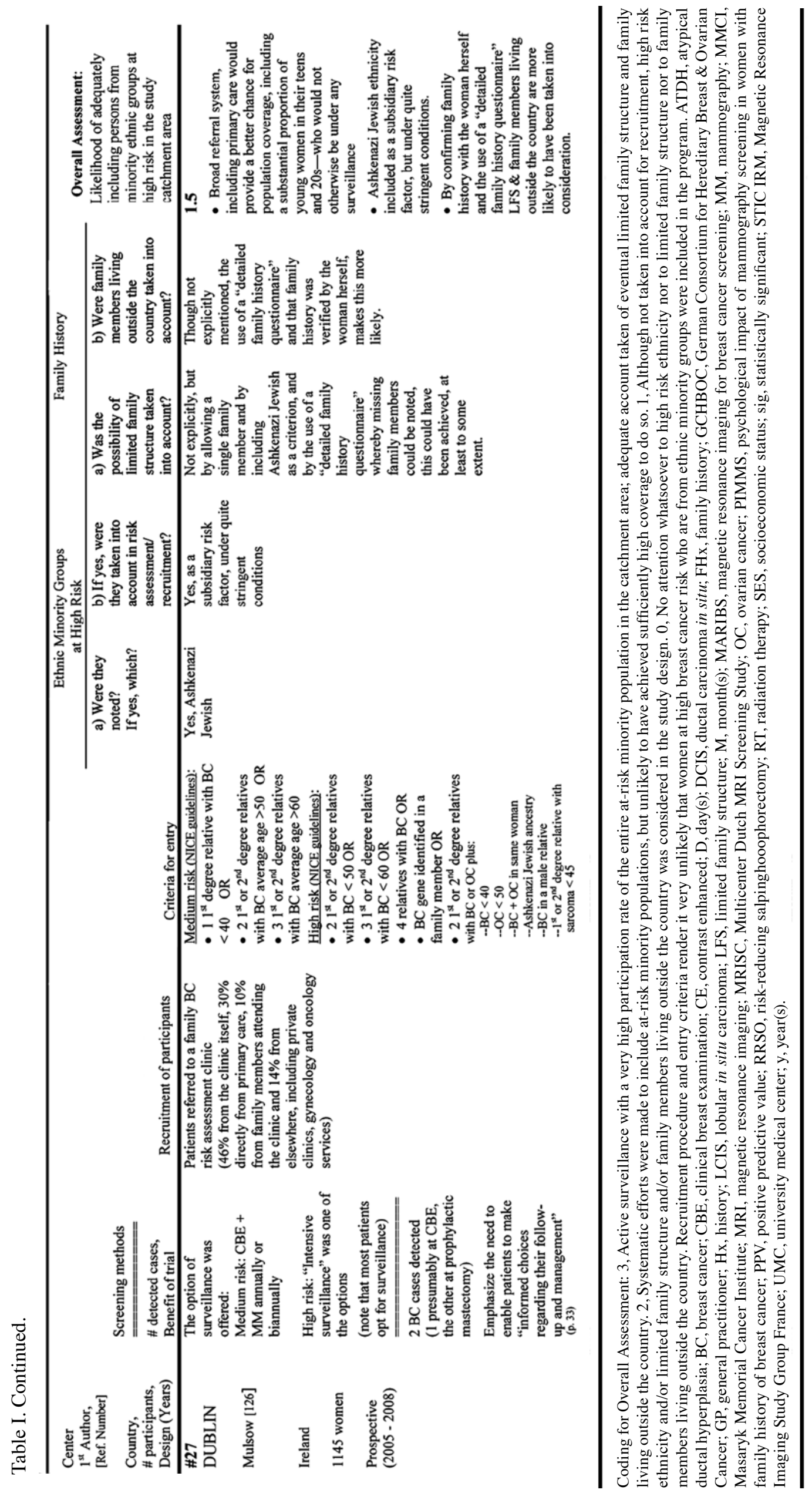


The Stockholm Center (\#23) (110-112) reported on 160 families receiving annual mammography and CBE. The two Norwegian Multicenter Studies (\#\#24 and 25) $(120,121)$ followed 754 and 491 women at high breast cancer risk for 5 and 3 years, respectively. In Study Center \#24 (120) CBE, mammography and in some cases ultrasound were used, and in \#25 (121) mammography, MRI and in some cases ultrasound.

In the Czech (Brno) Study Center (\#26) (123) MRI, mammography and ultrasound were provided to 284 women at high risk, with follow-up reported for 3 years. The Irish (Dublin) Study Center (\#27) (126) reported the results of 3 -year follow-up of 1145 women at medium and high breast cancer risk with the option offered of imaging surveillance using CBE and mammography.

\section{Benefits of imaging surveillance for women at high breast cancer risk as assessed in the 27 study centers}

In all the centers where it was applied, MRI was recommended for screening women at increased risk, since it showed the highest sensitivity and thereby provided early breast cancer detection, frequently while still carcinoma in situ. However, MRI also yielded many false positive results, often more than mammography. This low positive predictive value of MRI was of concern and other modalities (mammography and/or ultrasound) were also usually recommended. On the other hand, the Bonn Center (\#12) (79-82) found that MRI alone was sufficient among women with BRCA1 mutations. These authors reported that mammography did not provide additional information for early breast cancer detection in this group. Considering the heightened vulnerability to ionizing radiation among BRCA1 mutation carriers, these authors recommended that mammography be discontinued for this group. Similarly, in the Dutch Multicenter Study (\#1) (37-46) MRI appeared to be effective for $B R C A$ mutation carriers and was generally more sensitive than mammography. However, it was also noted that mammography detected some early cancers missed by MRI. Overall, the use of MRI and more intensive screening starting at a younger age provided earlier detection, such that there was a clear benefit for women with increased breast cancer risk.

From the Stockholm Study Center (\#23) (110-112) which focused on high-risk families, the decreasing age of cancer onset with successive generations was viewed as important for choosing surveillance modalities $(110,114)$. The investigators from the Dusseldorf Center $(\# 13)(84,85)$ stated that intensified early cancer detection programs for women at risk provide a less invasive option than chemoprevention or prophylactic surgery. Notwithstanding the high frequency of surveillance, these authors found it feasible to motivate at-risk women to participate. Despite the problems surrounding false positive findings, MRI was found to be acceptable by these women $(84,85)$. This latter conclusion was shared by authors from the Dutch Multicenter study (\#1) (38).

\section{Recruitment of women into the programs and consi- derations of ethnicity and high risk, including testing for relevant gene mutations}

Most of the study participants were recruited from specialized clinics for women at high risk. It was noted that self-referral or referral from primary care physicians was possible for some of these programs. The latter include: UK Study Centers (\#4 and \#8) MARIBS (52-67) and psychological impact of mammography screening in women with family history of breast cancer (PIMMS) (73,74), the Stockholm Study Center (\#23) (110-112), one of the Norwegian Multicenter Studies (\#24) (120), the Dublin Study Center (\#27) (126) and possibly the Czech (Brno) Study Center (\#26) (123). The explicit possibility of self-referral or referral from primary care physicians might improve the coverage of the catchment area and thereby might have increased the chances of including a broader sampling of women at high breast cancer risk.

Ethnicity, including ethnic minority groups at increased breast cancer risk was mentioned in some of the studies as part of their introduction or general discussion. In a study (47) which provided relevant background for the Dutch Multicenter MRI Screening Study, MRISC (\#1), a substantial percentage of women from minority ethnic backgrounds, including those with parents born elsewhere, were noted to have been referred to genetic counseling centers in the Netherlands. On the other hand, in the MRISC-B Study, requiring Dutch language proficiency (37) may have excluded a substantial percentage of ethnic minority women. Women from non-white minority ethnic backgrounds appear to have been under-represented in the UK MARIBS Study (\#4) comprising only $2.3 \%$ of the sample according to the reported data (62). The statement in Brozek et al (98): '(The) Polish population is not ethnically mixed because of the loss of a considerable number of ethnic groups from Poland's territory' (p. 329) could be interpreted to imply that for the Polish Szczecin Study (\#17) no special attention was given to minority groups that may be at high risk. In contrast, explicit appreciation of the country's ethnic diversity was indicated in a background article by the first author of the Czech Brno Study (\#26) (124).

For a few centers [Szczecin \#17 (96), Stockholm \#23 (110) and Brno \#26 (123)] relevant gene mutations were tested for some ethnic groups at high risk. It might be inferred from some studies $(79,83,107)$ that the Bonn and Vienna Centers (\#\#12 and 22) also tested for these gene mutations. In the Nightingale and PIMMS Studies from the UK (\#\#4 and 8) $(73,74)$ ande in the Dublin Study (\#27) (126) high risk ethnicity (Ashkenazi Jewish) was considered as a subsidiary factor under stringent conditions, i.e. that two relatives with breast or ovarian cancer had already been identified.

\section{Family history assessment, including reliance on national data registries}

Several of the study centers allowed a woman to be included in their program if she had a single family member with breast cancer or ovarian cancer diagnosed at a young age. This might partially have taken limited family structure into account. However, limited family structure per se (24) was not examined in any of the studies.

Family members outside the country were not explicitly taken into account in any of the studies. Some of the Centers, for example, the German Multicenter Study (\#11) (78), the Italian Modena Study (\#15) (91-93), the UK Study (\#10) (77) of young women with increased risk and the Polish Krakow Study 
(\#18) (99) described a very detailed procedure for taking a family history, and this may have facilitated inclusion of family who lived abroad. An adjudicating panel assessed the family history in the UK MARIBS study (\#4) and it might be assumed that this would ensure completeness of the family history data. On the other hand, the adjudicating panel could have introduced greater stringency, as assessed in the sub-study by Evans et al (55). In one of the most recent studies from the MARIBS and subsequent Nightingale Studies (\#4), it was explicitly recognized that there is a need for 'systematic assessment of family history in primary care or through population-based screening [to] identify appreciable numbers of women in their forties, eligible for additional surveillance' (56) (p. 993).

The Stockholm Center (\#23) $(110,114)$ and possibly the Multicenter Norwegian Study (\#24) $(121,122)$ relied on National Data Registries for identifying high risk families. Whereas this procedure would facilitate inclusion of at-risk family members living within the country, the likelihood is greater of missing family members outside the country. Moreover, first generation immigrants were defined a priori as 'without parents' in the Swedish database (117), rendering it even more difficult for first generation immigrant women to be included in the high risk programs.

\section{Overall assessment of the likelihood of including women at high breast cancer risk and who belong to minority ethnic groups into the 27 study centers}

Based on the above considerations, the overall assessment scores were low vis-à-vis the likelihood of adequately including women at high breast cancer risk, who belong to minority ethnic groups and who were residing in the study catchment area. Namely, the mean score was 0.72 [standard deviation = 0.31 (range $0.25-1.5$ )] from a possible range of 0-3. All but four of the study centers (UK Multicentre \#4, Stockholm \#23, Brno \#26 and Dublin \#27) had an overall assessment score $<1$ and, as indicated, none of the centers had a score $>1.5$.

\section{Broader considerations for Europe based on the present analysis}

The present analysis, based on a larger number of European centers and extended for several more years, confirms our previous findings (34) that for women at high risk of breast cancer, intensive screening programs, starting at a younger age and including magnetic resonance imaging were beneficial. The present review on the basis of this extended analysis also confirms our previous conclusion (34) that none of the European study centers made systematic efforts to include women from ethnic minority groups and who were at high breast cancer risk. High-risk ethnicity was not taken into account in recruitment of participants in most of the examined high-risk surveillance studies in Europe. The three exceptions (Nightingale Study \#4) (57), (PIMMS, Study \#8) $(73,74)$ and (Dublin, Study \#27) (126), as noted, considered high-risk ethnicity (Ashkenazi Jewish) as a subsidiary factor under stringent conditions, i.e. that two relatives with breast or ovarian cancer had already been identified. While a few of the examined study centers $(96,110,123)$ did test for the relevant gene mutations of ethnic minority groups at high risk, none of the studies reported active outreach efforts to ensure that these women participated in their programs.

Limited family structure (24) was not adequately considered in any of the reviewed study centers. It has been suggested that the probability models of breast cancer risk need to be revised so that limited family structure is taken into sufficient account. Limited family structure becomes especially problematic when there is a single case of breast cancer in the family. It is here, most notably that these models fail to identify high risk (25). When the family risk for disease is exceedingly high, these missing family links can become critical (16). For ethnic minority groups living in Europe, who have been exposed to war during which many family members have perished, these considerations regarding limited family structure warrant particular attention. For example, cases have been reported for which limited family history due to the Holocaust rendered timely detection of high risk for breast cancer very difficult (127).

Besides the possibility of limited family history, immigrants, refugees and ethnic minority groups, in general, are often geographically dispersed. Information about cancer occurrence may, therefore, be more difficult to obtain and confirm if the medical records are outside the country. We noted this to be particularly problematic for the study centers requiring documentation of all family cases and for those relying on the National Data Registries. None of the study centers explicitly indicated that efforts had been made to ascertain whether there was cancer incidence among family members outside the country.

In the attempt to obtain accurate information about family cancer history, the cultural as well as historical context should also be considered. Grief, fear and denial can hinder reporting the entire extent of family risk $(128,129)$. Insofar as the family has endured trauma, these considerations may become even more salient and protracted. For example, it has been noted that the offspring of Holocaust survivors (second generation) are very susceptible to psychological distress, such that when confronted with breast cancer, they react with extremely high levels of distress (130). This effect appears to be synergistic, such that women with breast cancer and whose parents were Holocaust survivors (Holocaust survivors were defined as those who had been in a concentration camp, forced labor camp or extermination camp in Europe during World War II) had much higher psychological distress than expected, based on the distress levels found for each of these factors alone $(131,132)$. Direct exposure to the Holocaust is also associated with increased risk of breast cancer and other malignancies (133). Other traumatic situations, especially those related to war and upheavals that are still occurring in various parts of the world may well have a similar effect on persons from the affected immigrant and refugee groups (130).

In Europe, disclosure of ethnicity per se may be problematic. Subsequent to World War II, a number of European countries avoided ethnic identification of individuals. It is also plausible that individuals can be reluctant to admit that their origin is other than that of the European country in which they are currently residing. This reluctance, while fully understandable, introduces yet more complexity regarding this topic within Europe. As counter-examples, in countries such as the Canada, USA and Australia, comprised of diverse 
immigrant populations since their establishment, asking about ethnicity in the relevant medical setting is not only acceptable, but is considered indispensable for providing adequate clinical care. In these countries, ethnic disclosure has been essential for ensuring appropriate attention to under-represented groups for clinical trials within oncology and elsewhere in medicine (134-136). Moreover, it is well-appreciated that special, often labor-intensive outreach efforts to underserved ethnic minority groups are needed, with attention to structural and attitudinal barriers to cancer screening (33,34,134,137-141). With specific regard to high breast cancer risk, it has been emphasized that 'identification of the ethnic group of families undergoing genetic counseling enables the geneticist and oncologist to make more specific choices...to simplify the clinical approach to genetic testing carried out on members of high-risk families' (p. vi93) (19).

Successful outreach to underserved ethnic minorities requires cultural competence, which includes both knowledge as well as sensitivity $(33,34,142-146)$. Culturally-tailored interventions have been very effective in increasing adherence to breast cancer screening guidelines among under-screened ethnic groups (147-150). As mentioned, women with a foreign birthplace and, especially, recent immigrants appear to be vulnerable for non-attendance in these screening programs (28-35). A poignant example is provided in a study (151) about Russian immigrants to Israel, whose preoccupation was with immediate survival needs, such that attitudes towards breast cancer screening were expressed as: 'I have no time for potential troubles' (p. 153).

This statement reflects another important concern regarding imaging surveillance of women with elevated risk of breast cancer, namely, the substantial possibility of obtaining false positive results from existing screening methods, including MRI. Indeed, in a multi-center study from the USA, Canada and Argentina, among women with increased breast cancer risk and who were eligible to undergo breast MRI, just over half agreed to do so (152). Claustrophobia was the most commonly noted reason for refusal, which may be related to general anxiety about the procedure and its possible results. Concern about additional biopsies or testing was explicitly cited by many women who declined to undergo MRI. It is plausible that this high refusal rate reflects a lack of confidence in the diagnostic accuracy of MRI. Although MRI is reported to be particularly sensitive for women with high breast cancer risk (153), the large number of false positive findings may have a deleterious effect upon quality of life (154). Thus, in the French Multicenter Study \#17, although women at high breast cancer risk who underwent MRI had less anxiety at baseline than women at lower risk who were not offered MRI, abnormal surveillance study results were associated with significantly increased anxiety (100). The possibilities for improving the specificity of MRI through e.g. magnetic resonance spectroscopy and diffusion-weighted imaging warrant attention in this context (155-161).

\section{Limitations and challenges of this review}

Together with our previous study (34), these are the first reviews, to the best of our knowledge, in which the special screening needs of ethnic minority women in Europe at high risk for breast cancer have been examined. Our search strategies were carefully conceived aiming for completeness. The scoring system was heuristic, because of the uncharted nature of this area of investigation. Nevertheless, we consider this scoring system to have good face validity. For some of the centers, inference was needed since the provided information was limited about recruitment of participants. We strove to avoid subjectivity in these ratings via two or more independent assessments.

Admittedly, the formal concept of limited family structure (24) is relatively new. Therefore, it might not be reasonable to expect this consideration to be fully incorporated into the study methodology of the examined centers. Nevertheless, the importance of family truncation as well as dispersion of family members outside the host country should certainly be a routine consideration to achieve adequate risk assessment. Simply stated, a complete family history should be taken 'without borders'.

Another limitation of the present review is that the percentage of ethnic minority women varies greatly across the various European countries, and this was not taken into account in our assessment. Different regions, even within the same country, may have very different proportions of persons who are not of the primary nationality of the country (i.e. immigrants, refugees as well as ethnic minorities having lived in the region for a long period of time). Nevertheless, the needs of such persons, whatever their prevalence in the population, still warrant attention.

A number of questions are raised by the present review. Firstly, in Europe we do not know the preferences of women with an ethnic minority background and who are at high breast cancer risk with regard to approaches to screening. Attitudes regarding disclosure of ethnic identity are also not known. Within this context, issues regarding the safety and security of disclosing one's ethnicity must be clearly addressed and guaranteed. It is known that trauma survivors and their immediate descendants can become extremely distressed when faced with breast cancer. However, it is not known how the generational experience of the severe trauma affects screening behavior among women at high breast cancer risk who are from ethnic minorities. Hence, the most effective cultural-specific strategies to enhance adherence to screening guidelines among these groups in Europe remain to be identified.

\section{Suggested next steps}

Population-based invitational breast cancer screening programs that already exist in many European countries would be an appropriate starting point for launching this initiative. These programs have a well-documented success in achieving high participation rates and lowering mortality from breast cancer (162-167). Outreach, including the use of multi-lingual media, is increasingly appreciated as an effective strategy for enhancing participation in breast cancer screening programs among ethnic minority groups. Inclusion of trusted community leaders may be particularly helpful $(150,168)$. This type of initiative is currently on-going, e.g. in Stockholm (169).

Several population-based invitational breast cancer screening programs operate in countries whose native populations are at increased risk of carrying deleterious breast cancer 
gene mutations. Analysis of cases of interval breast cancers from population-based screening programs underscores the importance of identifying women at high risk e.g. carriers of a more aggressive molecular phenotype such as $B R C A 1 / 2$ mutations (170). Screening at the population level for hereditary and familial cancer syndromes has been demonstrated to be a potentially viable strategy within the European setting (171). Population-based screening programs that tailor to risk profiles also represent a promising possibility, based on a recent study from Italy (172). Especially within such settings, systematic outreach to women at high risk from various ethnic groups would certainly be feasible.

As noted, several European countries have populationbased breast cancer screening programs. Unfortunately, however, even more European countries do not $(35,173)$. We would contend that efforts could be particularly promising insofar as they were coordinated with improved and more systematic breast cancer screening programs across Europe.

\section{Conclusions}

Women from ethnic minority groups in Europe and who are at high breast cancer risk do not appear to have sufficiently benefitted from existing high-risk screening programs. Systematic outreach targeting these populations, in a culturally sensitive manner, is needed. These efforts are likely to be most effective on a European-wide basis. Given the ever-increasing mobility of the global working force and socio-economic migration across national borders, the question of providing adequate breast cancer risk assessment for women of different ethnic origin is becoming more and more relevant. Furthermore, these efforts are in line with the European Union Council's initiative aimed at 'Reducing the Burden of Cancer in Europe' (174).

\section{Acknowledgements}

The present review was supported by Cancerfonden; Radiumhemmet Research Fund; the Müllerska Fund through the Royal Swedish Academy of Sciences; FoUU through Stockholm County Council and Karolinska Institutet Research Foundation to which the authors are grateful.

\section{References}

1. Parkin DM, Bray F, Ferlay J and Pisani P: Global cancer statistics, 2002. CA Cancer J Clin 55: 74-108, 2005.

2. Perry N, Broeders M, de Wolf C, Törnberg S, Holland R and von Karsa L: European guidelines for quality assurance in breast cancer screening and diagnosis Fourth edition - summary document. Ann Oncol 19: 614-622, 2008.

3. Sant M, Allemani C, Capocaccia R, Hakulinen T, Aareleid T, Coebergh JW, Coleman MP, Grosclaude P, Martinez C, Bell J, et al; EUROCARE Working Group: Stage at diagnosis is a key explanation of differences in breast cancer survival across Europe. Int J Cancer 106: 416-422, 2003.

4. Armstrong K, Moye E, Williams S, Berlin JA and Reynolds EE: Screening mammography in women 40 to 49 years of age: A systematic review for the American College of Physicians. Ann Intern Med 146: 516-526, 2007.

5. Saslow D, Boetes C, Burke W, Harms S, Leach MO, Lehman CD, Morris E, Pisano E, Schnall M, Sener S, et al; American Cancer Society Breast Cancer Advisory Group: American Cancer Society guidelines for breast screening with MRI as an adjunct to mammography. CA Cancer J Clin 57: 75-89, 2007.
6. Sabatino SA, Burns RB, Davis RB, Phillips RS, Chen YH and McCarthy EP: Breast carcinoma screening and risk perception among women at increased risk for breast carcinoma: Results from a national survey. Cancer 100: 2338-2346, 2004.

7. Evans JP, Skrzynia C, Susswein L and Harlan M: Genetics and the young woman with breast cancer. Breast Dis 23: 17-29, 2005-2006.

8. Klauber-DeMore N: Tumor biology of breast cancer in young women. Breast Dis 23: 9-15, 2005-2006.

9. Kurian AW, Hartman AR, Mills MA, Ford JM, Daniel BL and Plevritis SK: Opinions of women with high inherited breast cancer risk about prophylactic mastectomy: An initial evaluation from a screening trial including magnetic resonance imaging and ductal lavage. Health Expect 8: 221-233, 2005.

10. Clements A, Henderson BJ, Tyndel S, Evans G, Brain K, Austoker J and Watson E; PIMMS Study Management Group: Diagnosed with breast cancer while on a family history screening programme: An exploratory qualitative study. Eur J Cancer Care (Engl) 17: 245-252, 2008

11. Bermejo-Pérez MJ, Márquez-Calderón S and Llanos-Méndez A: Cancer surveillance based on imaging techniques in carriers of BRCA1/2 gene mutations: A systematic review. Br J Radiol 81: $172-179,2008$

12. Willey SC and Cocilovo C: Screening and follow-up of the patient at high risk for breast cancer. Obstet Gynecol 110: 1404-1416, 2007.

13. Armstrong AC and Evans GD: Management of women at high risk of breast cancer. BMJ 348: g2756, 2014.

14. Anderson E, Berg J, Black R, Bradshaw N, Campbell J, Cetnarskyj R, Drummond S, Davidson R, Dunlop J, Fordyce A, et al: Predicting breast cancer risk: Implications of a 'weak' family history. Fam Cancer 7: 361-366, 2008.

15. Eerola H, Blomqvist C, Pukkala E,Pyrhönen S and Nevanlinna H: Familial breast cancer in southern Finland: How prevalent are breast cancer families and can we trust the family history reported by patients? Eur J Cancer 36: 1143-1148, 2000.

16. Møller P, Hagen AI, Apold J, Maehle L, Clark N, Fiane B, Løvslett K, Hovig E and Vabø A: Genetic epidemiology of BRCA mutations - family history detects less than $50 \%$ of the mutation carriers. Eur J Cancer 43: 1713-1717, 2007.

17. Fackenthal JD and Olopade OI: Breast cancer risk associated with BRCA1 and BRCA2 in diverse populations. Nat Rev Cancer 7: 937-948, 2007.

18. Harboe TL, Eiberg H, Kern P, Ejlertsen B, Nedergaard L, Timmermans-Wielenga V, Nielsen IM and Bisgaard ML: A high frequent BRCA1 founder mutation identified in the Greenlandic population. Fam Cancer 8: 413-419, 2009.

19. Ferla R, Calò V, Cascio S, Rinaldi G, Badalamenti G, Carreca I, Surmacz E, Colucci G, Bazan V and Russo A: Founder mutations in BRCA1 and BRCA2 genes. Ann Oncol 18 (Suppl 6): vi93-vi98, 2007.

20. Iyevleva AG, Suspitsin EN, Kroeze K, Gorodnova TV, Sokolenko AP, Buslov KG, Voskresenskiy DA, Togo AV, Kovalenko SP, Stoep N, et al: Non-founder BRCA1 mutations in Russian breast cancer patients. Cancer Lett 298: 258-263, 2010.

21. Sagi M, Eilat A, Ben Avi L, Goldberg Y, Bercovich D, Hamburger T, Peretz T and Lerer I: Two BRCA1/2 founder mutations in Jews of Sephardic origin. Fam Cancer 10: 59-63, 2011.

22. Manchanda R, Legood R, Burnell M, McGuire A, Raikou M, Loggenberg K, Wardle J, Sanderson S, Gessler S, Side L, et al: Cost-effectiveness of population screening for BRCA mutations in Ashkenazi jewish women compared with family history-based testing. J Natl Cancer Inst 107: 380, 2015.

23. Corbex M, Bouzbid S and Boffetta P: Features of breast cancer in developing countries, examples from North-Africa. Eur J Cancer 50: 1808-1818, 2014

24. Weitzel JN, Lagos VI, Cullinane CA, Gambol PJ, Culver JO, Blazer KR, Palomares MR, Lowstuter KJ and MacDonald DJ: Limited family structure and BRCA gene mutation status in single cases of breast cancer. JAMA 297: 2587-2595, 2007.

25. Leu M, Czene K and Reilly M: The impact of truncation and missing family links in population-based registers on familial risk estimates. Am J Epidemiol 166: 1461-1467, 2007.

26. Leu M, Czene K and Reilly M: Bias correction of estimates of familial risk from population-based cohort studies. Int J Epidemiol 39: 80-88, 2010.

27. Weitzel JN: Limited Family structure and breast cancer risk. JAMA 298: Letter, 2007. http://dx.doi.org/10.1001/ jama.298.17.2007-b. 
28. Cohen M and Azaiza F: Early breast cancer detection practices, health beliefs, and cancer worries in Jewish and Arab women. Prev Med 41: 852-858, 2005.

29. Goel MS, Wee CC, McCarthy EP, Davis RB, Ngo-Metzger Q and Phillips RS: Racial and ethnic disparities in cancer screening: The importance of foreign birth as a barrier to care. J Gen Intern Med 18: 1028-1035, 2003

30. Li CI, Malone KE and Daling JR: Differences in breast cancer stage, treatment, and survival by race and ethnicity. Arch Intern Med 163: 49-56, 2003.

31. Lagerlund M, Maxwell AE, Bastani R, Thurfjell E, Ekbom A and Lambe M: Sociodemographic predictors of non-attendance at invitational mammography screening - a population-based register study (Sweden). Cancer Causes Control 13: 73-82, 2002.

32. Sassi F, Luft HS and Guadagnoli E: Reducing racial/ethnic disparities in female breast cancer: Screening rates and stage at diagnosis. Am J Public Health 96: 2165-2172, 2006.

33. Terán L, Baezconde-Garbanati L, Márquez M, Castellanos E and Belkić K: On-time mammography screening with a focus on Latinas with low income: A proposed cultural model. Anticancer Res 27 (6C): 4325-4338, 2007.

34. Belkić K, Cohen M, Márquez M, Mints M, Wilczek B, Berman AH, Castellanos E and Castellanos M: Screening of high-risk groups for breast and ovarian cancer in Europe: A focus on the Jewish population. Oncol Rev 4: 233-267, 2010.

35. Sándor J, Havasi V, Kiss I, Szücs M, Brázay L, Sebestyén A and Ember I: Small area inequalities in breast cancer mortality and screening. Magy Onkol 46: 139-145, 2002 (In Hungarian).

36. Copson E, Maishman T, Gerty S, Eccles B, Stanton L, Cutress RI, Altman DG, Durcan L, Simmonds P, Jones L, et al; POSH study steering group: Ethnicity and outcome of young breast cancer patients in the United Kingdom: The POSH study. Br J Cancer 110: 230-241, 2014.

37. den Heijer M, Seynaeve C, Vanheusden K, Timman R, Duivenvoorden HJ, Tilanus-Linthorst M, Menke-Pluijmers MB and Tibben A: Long-term psychological distress in women at risk for hereditary breast cancer adhering to regular surveillance: A risk profile. Psychooncology 22: 598-604, 2013.

38. Essink-Bot ML, Rijnsburger AJ, van Dooren S, de Koning HJ and Seynaeve C: Women's acceptance of MRI in breast cancer surveillance because of a familial or genetic predisposition. Breast 15: 673-676, 2006

39. Kriege M, Brekelmans CT, Boetes C, Rutgers EJ, Oosterwijk JC Tollenaar RA, Manoliu RA, Holland R, de Koning HJ and Klijn JG: MRI screening for breast cancer in women with familial or genetic predisposition: Design of the Dutch National Study (MRISC). Fam Cancer 1: 163-168, 2001

40. Kriege M, Brekelmans CTM, Boetes C, Besnard PE, Zonderland HM, Obdeijn IM, Manoliu RA, Kok T, Peterse H, Tilanus-Linthorst MM, et al; Magnetic Resonance Imaging Screening Study Group: Efficacy of MRI and mammography for breast-cancer screening in women with a familial or genetic predisposition. N Engl J Med 351: 427-437, 2004.

41. Kriege M,Brekelmans CT, Boetes C, Muller SH,Zonderland HM, Obdeijn IM, Manoliu RA, Kok T, Rutgers EJ, de Koning HJ, et al; Dutch MRI Screening (MRISC) Study Group: Differences between first and subsequent rounds of the MRISC breast cancer screening program for women with a familial or genetic predisposition. Cancer 106: 2318-2326, 2006

42. Kriege M, Brekelmans CT, Peterse H, Obdeijn IM, Boetes C, Zonderland HM, Muller SH, Kok T, Manoliu RA, Besnard AP, et al: Tumor characteristics and detection method in the MRISC screening program for the early detection of hereditary breast cancer. Breast Cancer Res Treat 102: 357-363, 2007.

43. Obdeijn IM, Loo CE, Rijnsburger AJ, Wasser MN, Bergers E, Kok T, Klijn JG and Boetes C: Assessment of false-negative cases of breast MR imaging in women with a familial or genetic predisposition. Breast Cancer Res Treat 119: 399-407, 2010.

44. Pieterse K, van Dooren S, Seynaeve C, Bartels CC, Rijnsburger AJ, de Koning HJ, Klijn JG, van Elderen T, Tibben A and Duivenvoorden HJ: Passive coping and psychological distress in women adhering to regular breast cancer surveillance. Psychooncology 16: 851-858, 2007.

45. Rijnsburger AJ, Obdeijn I-M, Kaas R, Tilanus-Linthorst MMA, Boetes C, Loo CE, Wasser MN, Bergers E, Kok T, Muller SH, et al: BRCA1-associated breast cancers present differently from BRCA2-associated and familial cases: Long-term follow-up of the Dutch MRISC Screening Study. J Clin Oncol 28: 5265-5273, 2010 .
46. Tilanus-Linthorst MM, Kriege M, Boetes C, Hop WC, Obdeijn IM, Oosterwijk JC, Peterse HL, Zonderland HM, Meijer S, Eggermont AM, et al: Hereditary breast cancer growth rates and its impact on screening policy. Eur J Cancer 41: $1610-1617,2005$

47. Albada A, Werrett J, Van Dulmen S, Bensing JM, Chapman C, Ausems MG and Metcalfe A: Breast cancer genetic counselling referrals: How comparable are the findings between the UK and the Netherlands? J Community Genet 2: 233-247, 2011.

48. Boetes C: Update on screening breast MRI in high-risk women. Obstet Gynecol Clin North Am 38: 149-158, viii-ix, 2011.

49. Lammens CR, Bleiker EM, Aaronson NK, Wagner A, Sijmons RH, Ausems MG, Vriends AH, Ruijs MW, van Os TA, Spruijt L, et al: Regular surveillance for Li-Fraumeni Syndrome: Advice, adherence and perceived benefits. Fam Cancer 9: 647-654, 2010.

50. Fakkert IE, Jansen L, Meijer K, Kok T, Oosterwijk JC, Mourits MJ and de Bock GH: Breast cancer screening in BRCA1 and BRCA2 mutation carriers after risk reducing salpingo-oophorectomy. Breast Cancer Res Treat 129: 157-164, 2011

51. Tilanus-Linthorst MM, Obdeijn IM, Bartels KC, de Koning HJ and Oudkerk M: First experiences in screening women at high risk for breast cancer with MR imaging. Breast Cancer Res Treat 63: 53-60, 2000.

52. Brown J, Coulthard A, Dixon AK, Dixon JM, Easton DF, Eeles RA, Evans DG, Gilbert FG, Hayes C, Jenkins JP, et al; UK MRI Breast Screening Study Advisory Group: Protocol for a national multi-centre study of magnetic resonance imaging screening in women at genetic risk of breast cancer. Breast 9: 78-82, 2000.

53. Brown J, Coulthard A, Dixon AK, Dixon JM, Easton DF, Eeles RA, Evans DG, Gilbert FG, Hayes C, Jenkins JP, et al; UK MRI Breast Screening Study Advisory Group: Rationale for a national multi-centre study of magnetic resonance imaging screening in women at genetic risk of breast cancer. Breast 9: 72-77, 2000.

54. Brown J, Buckley D, Coulthard A, Dixon AK, Dixon JM, Easton DF, Eeles RA, Evans DG, Gilbert FG, Graves M, et al; UK MRI Breast Screening Study Advisory Group: Magnetic resonance imaging screening in women at genetic risk of breast cancer: Imaging and analysis protocol for the UK multicentre study. Magn Reson Imaging 18: 765-776, 2000.

55. Evans DG, Lennard F, Pointon LJ, Ramus SJ, Gayther SA, Sodha N, Kwan-Lim GE, Leach MO, Warren R, Thompson D, et al; UK Study of MRI Screening for Breast Cancer in Women at High Risk (MARIBS): Eligibility for magnetic resonance imaging screening in the United Kingdom: Effect of strict selection criteria and anonymous DNA testing on breast cancer incidence in the MARIBS Study. Cancer Epidemiol Biomarkers Prev 18: 2123-2131, 2009.

56. Evans DG, Brentnall AR, Harvie M, Dawe S, Sergeant JC, Stavrinos P, Astley S, Wilson M, Ainsworth J, Cuzick J, et al: Breast cancer risk in young women in the national breast screening programme: Implications for applying NICE guidelines for additional screening and chemoprevention. Cancer Prev Res (Phila) 7: 993-1001, 2014.

57. Evans DG, Kesavan N, Lim Y, Gadde S, Hurley E, Massat NJ, Maxwell AJ, Ingham S, Eeles R, Leach MO, et al; MARIBS Group: MRI breast screening in high-risk women: Cancer detection and survival analysis. Breast Cancer Res Treat 145: 663-672, 2014

58. Gilbert FJ, Warren RM, Kwan-Lim G, Thompson DJ, Eeles RA, Evans DG and Leach MO; United Kingdom Magnetic Resonance Imaging in Breast Screening (MARIBS) Study Group: Cancers in BRCA1 and BRCA2 carriers and in women at high risk for breast cancer: MR imaging and mammographic features. Radiology 252: 358-368, 2009.

59. Griebsch I, Brown J, Boggis C, Dixon A, Dixon M, Easton D, Eeles R, Evans DG, Gilbert FJ, Hawnaur J, et al; UK Magnetic Resonance Imaging in Breast Screening (MARIBS) Study Group: Cost-effectiveness of screening with contrast enhanced magnetic resonance imaging vs X-ray mammography of women at a high familial risk of breast cancer. Br J Cancer 95: 801-810, 2006.

60. Gui GP, Hogben RK, Walsh G, A'Hern R and Eeles R: The incidence of breast cancer from screening women according to predicted family history risk: Does annual clinical examination add to mammography? Eur J Cancer 37: 1668-1673, 2001. 
61. Gui GP, Kadayaprath G, Darhouse N, Self J, Ward A, A'Hern R and Eeles R: Clinical outcome and service implications of screening women at increased breast cancer risk from a family history. Eur J Surg Oncol 32: 719-724, 2006.

62. Hutton J, Walker LG, Gilbert FJ, Evans DG, Eeles R, Kwan-Lim GE, Thompson D, Pointon LJ, Sharp DM and Leach MO; UK Study Group for MRI Screening in Women at High Risk Study: Psychological impact and acceptability of magnetic resonance imaging and X-ray mammography: The MARIBS Study. Br J Cancer 104: 578-586, 2011.

63. Leach MO, Eeles RA, Turnbull LW, Dixon AK, Brown J, Hoff RJ, Coulthard A, Dixon JM, Easton DF, Evans DG, et al; Magnetic Resonance Imaging as a Method of Screening for Breast Cancer Advisory Group: The UK national study of magnetic resonance imaging as a method of screening for breast cancer (MARIBS). J Exp Clin Cancer Res 21 (Suppl 3): 107-114, 2002.

64. Leach MO, Boggis CR, Dixon AK, Easton DF, Eeles RA, Evans DG, Gilbert FJ, Griebsch I, Hoff RJ, Kessar P, et al; MARIBS study group: Screening with magnetic resonance imaging and mammography of a UK population at high familial risk of breast cancer: A prospective multicentre cohort study (MARIBS). Lancet 365: 1769-1778, 2005.

65. Thompson DJ, Leach MO, Kwan-Lim G, Gayther SA, Ramus SJ, Warsi I, Lennard F, Khazen M, Bryant E, Reed S, et al; UK study of MRI screening for breast cancer in women at high risk (MARIBS): Assessing the usefulness of a novel MRI-based breast density estimation algorithm in a cohort of women at high genetic risk of breast cancer: The UK MARIBS study. Breast Cancer Res 11: R80, 2009.

66. Tilanus-Linthorst MM, Obdeijn IM and Bartels KC: MARIBS study. Lancet 366: 291-292, 2005.

67. Warren RM, Thompson D, Pointon LJ, Hoff R, Gilbert FJ, Padhani AR, Easton DF, Lakhani SR and Leach MO Collaborators in the United Kingdom Medical Research Council Magnetic Resonance Imaging in Breast Screening (MARIBS) Study: Evaluation of a prospective scoring system designed for a multicenter breast MR imaging screening study. Radiology 239 : 677-685, 2006

68. Gilbert FJ: Breast cancer screening in high risk women. Cancer Imaging 8 Spec No A: S6-S9, 2008. http://dx.doi. org $/ 10.1102 / 1470-7330.2008 .9002$.

69. Leach MO: Breast cancer screening in women at high risk using MRI. NMR Biomed 22: 17-27, 2009.

70. Murday V, Pears R, Ball J, Eeles R and Hodgson S: An audit of screening for familial breast cancer before 50 years in the South Thames Region - have we got it right? Fam Cancer 3: 29-34, 2004.

71. Kollias J, Sibbering DM, Blamey RW, Holland PA, Obuszko Z, Wilson AR, Evans AJ, Ellis IO and Elston CW: Screening women aged less than 50 years with a family history of breast cancer. Eur J Cancer 34: 878-883, 1998.

72. Reis MM, Tavakoli M, Dewar J, Goudie D, Cook A, McLeish L, Young D, Kenyon J and Steel M: Evaluation of a surveillance programme for women with a family history of breast cancer. J Med Genet 46: 319-323, 2009.

73. Brain K, Henderson BJ, Tyndel S, Bankhead C, Watson E, Clements A and Austoker J; PIMMS Study Management Group: Predictors of breast cancer-related distress following mammography screening in younger women on a family history breast screening programme. Psychooncology 17: 1180-1188, 2008.

74. Tyndel S, Clements A, Bankhead C, Henderson BJ, Brain K, Watson E and Austoker J; PIMMS Study Management Group: Mammographic screening for young women with a family history of breast cancer: Knowledge and views of those at risk. Br J Cancer 99: 1007-1012, 2008.

75. Evans DG, Harvie M, Bundred N and Howell A: Uptake of breast cancer prevention and screening trials. J Med Genet 47: 853-855, 2010.

76. Howell SJ, Searle C, Goode V, Gardener T, Linton K, Cowan RA, Harris MA, Hopwood P, Swindell R, Norman A, et al: The UK national breast cancer screening programme for survivors of Hodgkin lymphoma detects breast cancer at an early stage. Br J Cancer 101: 582-588, 2009.

77. Evans DG, Thomas S, Caunt J, Roberts L, Howell A, Wilson M, Fox R, Sibbering DM, Moss S, Wallis MG, et al; FH02 study group: Mammographic surveillance in women aged 35-39 at enhanced familial risk of breast cancer (FH02). Fam Cancer 13: 13-21, 2014.
78. Schmutzler RK, Rhiem K, Breuer P, Wardelmann E, Lehnert M, Coburger S and Wappenschmidt B: Outcome of a structured surveillance programme in women with a familial predisposition for breast cancer. Eur J Cancer Prev 15: 483-489, 2006

79. Kuhl CK: High-risk screening: Multi-modality surveillance of women at high risk for breast cancer (proven or suspected carriers of a breast cancer susceptibility gene). J Exp Clin Cancer Res 21 (Suppl 3): 103-106, 2002.

80. Kuhl CK, Schrading S, Leutner CC, Morakkabati-Spitz N, Wardelmann E, Fimmers R, Kuhn W and Schild HH: Mammography, breast ultrasound, and magnetic resonance imaging for surveillance of women at high familial risk for breast cancer. J Clin Oncol 23: 8469-8476, 2005.

81. Kuhl CK, Kuhn W and Schild H: Management of women at high risk for breast cancer: New imaging beyond mammography. Breast 14: 480-486, 2005.

82. Schrading S and Kuhl CK: Mammographic, US, and MR imaging phenotypes of familial breast cancer. Radiology 246: 58-70, 2008.

83. Meindl A; German Consortium for Hereditary Breast and Ovarian Cancer: Comprehensive analysis of 989 patients with breast or ovarian cancer provides BRCA1 and BRCA2 mutation profiles and frequencies for the German population. Int J Cancer 97: 472-480, 2002

84. Lux MP, Ackermann S, Nestle-Krämling C, Goecke TO, Niederacher D, Bodden-Heidrich R, Bender HG, Beckmann MW and Fasching PA: Use of intensified early cancer detection in high-risk patients with familial breast and ovarian cancer. Eur J Cancer Prev 14: 399-411, 2005.

85. Lux MP, Ackermann S, Bani MR, Nestle-Krämling C, Goecke TO, Niederacher D, Bodden-Heidrich R, Bender HG, Beckmann MW and Fasching PA: Age of uptake of early cancer detection facilities by low-risk and high-risk patients with familial breast and ovarian cancer. Eur J Cancer Prev 14: 503-511, 2005.

86. Sardanelli F, Podo F, D’Agnolo G, Verdecchia A, Santaquilani M, Musumeci R, Trecate G, Manoukian S, Morassut S, de Giacomi C, et al; High Breast Cancer Risk Italian Trial: Multicenter comparative multimodality surveillance of women at genetic-familial high risk for breast cancer (HIBCRIT study): Interim results. Radiology 242: 698-715, 2007.

87. Sardanelli F, Podo F, Santoro F, Manoukian S, Bergonzi S, Trecate G, Vergnaghi D, Federico M, Cortesi L, Corcione S, et al; High Breast Cancer Risk Italian 1 (HIBCRIT-1) Study: Multicenter surveillance of women at high genetic breast cancer risk using mammography, ultrasonography, and contrastenhanced magnetic resonance imaging (the high breast cancer risk Italian 1 study): Final results. Invest Radiol 46: 94-105, 2011.

88. Sardanelli F, Giuseppetti GM, Canavese G, Cataliotti L, Corcione S, Cossu E, Federico M, Marotti L, Martincich L, Panizza $\mathrm{P}$, et al: Indications for breast magnetic resonance imaging. Consensus document 'Attualità in senologia', Florence 2007. Radiol Med (Torino) 113: 1085-1095, 2008.

89. Manfrin E, Mariotto R, Remo A, Reghellin D, Falsirollo F, Dalfior D, Bricolo P, Piazzola E and Bonetti F: Benign breast lesions at risk of developing cancer--a challenging problem in breast cancer screening programs: Five years' experience of the Breast Cancer Screening Program in Verona (1999-2004). Cancer 115: 499-507, 2009.

90. Santoro F, Podo F and Sardanelli F: MRI screening of women with hereditary predisposition to breast cancer: Diagnostic performance and survival analysis. Breast Cancer Res Treat 147: 685-687, 2014

91. Cortesi L, Turchetti D, Marchi I, Fracca A, Canossi B, Rachele B, Silvia R, Rita PA, Pietro T and Massimo F: Breast cancer screening in women at increased risk according to different family histories: An update of the Modena Study Group experience. BMC Cancer 6: 210, 2006.

92. Cortesi L, Pecchi A, De Matteis E, FilieriE, Battista R, Canossi B, Torricelli $\mathrm{P}$ and Federico M: MRI in high risk women: Benefits and problems. Eur J Radiol 81 (Suppl 1): S19-S20, 2012.

93. Federico M, Maiorana A, Mangone L, Turchetti D, Canossi B, Cortesi L, Romagnoli R and Silingardi V: Identification of families with hereditary breast and ovarian cancer for clinical and mammographic surveillance: The Modena Study Group proposal. Breast Cancer Res Treat 55: 213-221, 1999.

94. Cortesi L, Masini C, Cirilli C, Medici V, Marchi I, Cavazzini G, Pasini G, Turchetti D and Federico M: Favourable ten-year overall survival in a Caucasian population with high probability of hereditary breast cancer. BMC Cancer 10: 90, 2010. 
95. Trecate G, Vergnaghi D, Manoukian S, Bergonzi S, Scaperrotta G, Marchesini M, Ferranti C, Peissel B, Spatti G, Bohm S, et al: MRI in the early detection of breast cancer in women with high genetic risk. Tumori 92: 517-523, 2006.

96. Gronwald J, Byrski T, Huzarski T, Cybulski C, Stawicka M, Szwiec M, Debniak T, Tulman A, Sun P, Oszurek O, et al: A survey of preventive measures among BRCA1 mutation carriers from Poland. Clin Genet 71: 153-157, 2007.

97. Górski B, Jakubowska A, Huzarski T, Byrski T, Gronwald J, Grzybowska E, Mackiewicz A, Stawicka M, Bebenek M, Sorokin D, et al: A high proportion of founder BRCA1 mutations in Polish breast cancer families. Int J Cancer 110: 683-686, 2004.

98. Brozek I, Cybulska C, Ratajska M, Piatkowska M, Kluska A, Balabas A, Dabrowska M, Nowakowska D, Niwinska A, Pamula-Pilat J, et al: Prevalence of the most frequent BRCA1 mutations in Polish population. J Appl Genet 52: 325-330, 2011

99. Popiela TJ, Kibil W, Herman-Sucharska I and Urbanik A: The use of magnetic resonance mammography in women at increased risk for developing breast cancer. Wideochir Inne Tech Malo Inwazyjne 8: 55-62, 2013.

100. Brédart A, Kop JL, Fall M, Pelissier S, Simondi C, Dolbeault S, Livartowski A and Tardivon A; Magnetic Resonance Imaging study group (STIC IRM 2005): Anxiety and specific distress in women at intermediate and high risk of breast cancer before and after surveillance by magnetic resonance imaging and mammography versus standard mammography. Psychooncology 21: 1185-1194, 2012.

101. Brédart A, Kop JL, Fall M, Pelissier S, Simondi C, Dolbeault S, Livartowski A and Tardivon A; Magnetic Resonance Imaging study group (STIC IRM 2005): Perception of care and experience of examination in women at risk of breast cancer undergoing intensive surveillance by standard imaging with or without MRI. Patient Educ Couns 86: 405-413, 2012.

102. Daguet E, Malhaire C, Hardit C, Athanasiou A, El Khoury C, Thibault F, Ollivier L and Tardivon A; Groupe Femmes à Risque de l'Institut Curie: MR breast screening in patients with genetic mutation. J Radiol 89: 783-790, 2008 (In French).

103. Dorval M, Noguès C, Berthet P, Chiquette J, Gauthier-Villars M, Lasset C, Picard C, Plante M, Simard J and Julian-Reynier C, INHERIT BRCAs; GENEPSO Cohort: Breast and ovarian cancer screening of non-carriers from BRCA1/2 mutationpositive families: 2-year follow-up of cohorts from France and Quebec. Eur J Hum Genet 19: 494-499, 2011.

104. Eisinger F, Bressac B, Castaigne D, Cottu PH, Lansac J, Lefranc JP, Lesur A, Noguès C, Pierret J, Puy-Pernias S, et al: Identification and management of hereditary predisposition to cancer of the breast and the ovary (update 2004). Bull Cancer 91: 219-237, 2004 (In French).

105. Eisinger F: Breast cancer screening for women with a strong familial risk. Bull Cancer 92: 874-884, 2005 (In French).

106. Lapierre-Combes M, Rousset J, Combes E, Chinelatto S, Dupré PF and André V: Retrospective study conducted in northern Finistère about the role of breast MRI in normal breast screening, experience in 51 patients. Gynecol Obstet Fertil 37: 401-409, 2009 (In French).

107. Riedl CC, Ponhold L, Flöry D, Weber M, Kroiss R, Wagner T, Fuchsjäger M and Helbich TH: Magnetic resonance imaging of the breast improves detection of invasive cancer, preinvasive cancer, and premalignant lesions during surveillance of women at high risk for breast cancer. Clin Cancer Res 13: 6144-6152, 2007 .

108. Kroiss R, Winkler V, Bikas D, Fleischmann E, Mainau C, Frommlet F, Muhr D, Fuerhauser C, Tea M, Bittner B, et al; Austrian Hereditary Breast and Ovarian Cancer Group: Younger birth cohort correlates with higher breast and ovarian cancer risk in European BRCA1 mutation carriers. Hum Mutat 26: 583-589, 2005.

109. Kroiss R, Winkler V, Kalteis K, Bikas D, Rudas M, Tea M, Fuerhauser C, Muhr D, Cerny H, Glueck S, et al; Austrian Hereditary Breast and Ovarian Cancer Group: Prevalence of pre-malignant and malignant lesions in prophylactic mastectomy specimens of BRCA1 mutation carriers: Comparison with a control group. J Cancer Res Clin Oncol 134: 1113-1121, 2008.

110. Arver B, Borg A and Lindblom A: First BRCA1 and BRCA2 gene testing implemented in the health care system of Stockholm. Genet Test 5: 1-8, 2001.

111. Arver B, Haegermark A, Platten U,Lindblom A and Brandberg Y: Evaluation of psychosocial effects of pre-symptomatic testing for breast/ovarian and colon cancer pre-disposing genes: A 12-month follow-up. Fam Cancer 3: 109-116, 2004.
112. Zelada-Hedman M, Wasteson Arver B, Claro A, Chen J, Werelius B, Kok H, Sandelin K, Håkansson S, Andersen TI, Borg A, et al: A screening for BRCA1 mutations in breast and breast-ovarian cancer families from the Stockholm region. Cancer Res 57: 2474-2477, 1997.

113. Arver B, Isaksson K, Atterhem H, Baan A, Bergkvist L, Brandberg Y, Ehrencrona H, Emanuelsson M, Hellborg H, Henriksson $\mathrm{K}$, et al: Bilateral prophylactic mastectomy in Swedish women at high risk of breast cancer: A national survey. Ann Surg 253: 1147-1154, 2011

114. Brandt A, Lorenzo Bermejo J, Sundquist J and Hemminki K: Breast cancer risk in women who fulfill high-risk criteria: At what age should surveillance start? Breast Cancer Res Treat 121: $133-141,2010$

115. Czene K, Reilly M, Hall P and Hartman M: A constant risk for familial breast cancer? A population-based family study. Breast Cancer Res 11: R30, 2009.

116. Hemminki K, Ji J and Försti A: Risks for familial and contralateral breast cancer interact multiplicatively and cause a high risk Cancer Res 67: 868-870, 2007.

117. Hemminki K, Mousavi SM, Sundquist J and Brandt A: Does the breast cancer age at diagnosis differ by ethnicity? A study on immigrants to Sweden. Oncologist 16: 146-154, 2011.

118. Margolin S, Werelius B, Fornander T and Lindblom A: BRCA1 mutations in a population-based study of breast cancer in Stockholm county. Genet Test 8: 127-132, 2004.

119. Von Wachenfeldt A, Brandberg Y, Johansson H and Fornander T: Socioeconomic status and quality of life of women with family history of breast cancer attending an oncogenetic counseling clinic: A comparison with general population. Acta Oncol 48: 86-92, 2009.

120. Dørum A, Heimdal K, Løvslett K, Kristensen G, Hansen LJ, Sandvei R, Schiefloe A, Hagen B, Himmelmann A, Jerve F, et al: Prospectively detected cancer in familial breast/ovarian cancer screening. Acta Obstet Gynecol Scand 78: 906-911, 1999.

121. Hagen AI, Kvistad KA, Maehle L, Holmen MM, Aase H, Styr B, Vabø A, Apold J, Skaane P and Møller P: Sensitivity of MRI versus conventional screening in the diagnosis of BRCAassociated breast cancer in a national prospective series. Breast 16: $367-374,2007$

122. Albrektsen G, Heuch I and Thoresen SØ: Histological type and grade of breast cancer tumors by parity, age at birth, and time since birth: A register-based study in Norway. BMC Cancer 10: 226,2010

123. Foretova L, Petrakova K, Palacova M, Kalabova R, Svoboda M, Navratilova M, Schneiderova M, Bolcak K, Krejci E, Drazan L, et al: Genetic testing and prevention of hereditary cancer at the MMCI--over 10 years of experience. Klin Onkol 23: 388-400, 2010.

124. Foretova L, Machackova E, Navratilova M, Pavlu H, Hruba M, Lukesova $\mathrm{M}$ and Valik D: BRCA1 and BRCA2 mutations in women with familial or early-onset breast/ovarian cancer in the Czech Republic. Hum Mutat 23: 397-398, 2004

125. Mateju M, Stribrna J, Zikan M, Kleibl Z, Janatova M, Kormunda S, Novotny J, Soucek P, Petruzelka L and Pohlreich P: Population-based study of BRCA1/2 mutations: Family history based criteria identify minority of mutation carriers. Neoplasma 57: 280-285, 2010

126. Mulsow J, Lee J, Dempsey C, Rothwell J and Geraghty JG: Establishing a family risk assessment clinic for breast cancer. Breast J 15 (Suppl 1): S33-S38, 2009.

127. Brandt RT and Lynch HT: BRCA1 and BRCA2: To test or not to test. Breast Cancer Res Treat 67: 187-188, 2001.

128. Surbone A: Ethical implications of genetic testing for breast cancer susceptibility. Crit Rev Oncol Hematol 40: 149-157, 2001

129. Márquez M, Belkić K, Nilsson S and Holmberg AR: Genetic testing in patients with hereditary cancer risk: Social, ethical and legal considerations. Instit Investig Jurid 383: 295-340, 2007.

130. Baider L, Peretz T, Hadani PE, Perry S, Avramov R and De-Nour AK: Transmission of response to trauma? Secondgeneration Holocaust survivors' reaction to cancer. Am J Psychiatry 157: 904-910, 2000.

131. Baider L, Goldzweig G, Ever-Hadani P and Peretz T: Psychological distress and coping in breast cancer patients and healthy women whose parents survived the Holocaust. Psychooncology 15: 635-646, 2006.

132. Baider L, Goldzweig G, Ever-Hadani P and Peretz T: Breast cancer and psychological distress: Mothers' and daughters traumatic experiences. Support Care Cancer 16: 407-414, 2008. 
133. Keinan-Boker L, Vin-Raviv N, Liphshitz I, Linn S and Barchana M: Cancer incidence in Israeli Jewish survivors of World War II. J Natl Cancer Inst 101: 1489-1500, 2009.

134. Brown DR, Fouad MN, Basen-Engquist K and TortoleroLuna G: Recruitment and retention of minority women in cancer screening, prevention, and treatment trials. Ann Epidemiol 10 (Suppl 8): S13-S21, 2000.

135. Newman LA, Hurd T, Leitch M, Kuerer HM, Diehl K, Lucci A, Giuliano A, Hunt KK, Putnam W and Wells SA: A report on accrual rates for elderly and minority-ethnicity cancer patients to clinical trials of the American College of Surgeons Oncology Group. J Am Coll Surg 199: 644-651, 2004.

136. Guevara C, Cook C, Herback N, Pietrobon R, Jacobs DO and Vail TP: Gender, racial, and ethnic disclosure in NIH K-Award funded diabetes and obesity clinical trials. Account Res 13: 311-324, 2006.

137. Azaiza F, Cohen M, Awad M and Daoud F: Factors associated with low screening for breast cancer in the Palestinian Authority: Relations of availability, environmental barriers, and cancer-related fatalism. Cancer 116: 4646-4655, 2010.

138. Bobo JK, Shapiro JA and Brustrom J: Efforts to locate lowincome women for a study on mammography rescreening: Implications for public health practice. J Community Health 31 : 249-261, 2006.

139. Garbers S, Jessop DJ, Foti H, Uribelarrea M and Chiasson MA: Barriers to breast cancer screening for low-income Mexican and Dominican women in New York City. J Urban Health 80: 81-91, 2003.

140. Otero-Sabogal R, Stewart S, Sabogal F, Brown BA and PérezStable EJ: Access and attitudinal factors related to breast and cervical cancer rescreening: Why are Latinas still underscreened? Health Educ Behav 30: 337-359, 2003.

141. Otero-Sabogal R, Owens D, Canchola J, Golding JM, Tabnak F and Fox P: Mammography rescreening among women of diverse ethnicities: Patient, provider, and health care system factors. J Health Care Poor Underserved 15: 390-412, 2004.

142. Erwin DO, Johnson VA, Trevino M, Duke K, Feliciano L and Jandorf L: A comparison of African American and Latina social networks as indicators for culturally tailoring a breast and cervical cancer education intervention. Cancer 109 (Suppl 2): 368-377, 2007.

143. Glanz K, Croyle RT, Chollette VY and Pinn VW: Cancer-related health disparities in women. Am J Public Health 93: 292-298, 2003.

144. Meiser B, Eisenbruch M, Barlow-Stewart K, Tucker K, Steel Z and Goldstein D: Cultural aspects of cancer genetics: Setting a research agenda. J Med Genet 38: 425-429, 2001.

145. Remennick L: The challenge of early breast cancer detection among immigrant and minority women in multicultural societies. Breast J 12 (Suppl 1): S103-S110, 2006.

146. Valdez A, Banerjee K, Ackerson L and Fernandez M: A multimedia breast cancer education intervention for low-income Latinas. J Community Health 27: 33-51, 2002.

147. Borrayo EA: Where's Maria? A video to increase awareness about breast cancer and mammography screening among lowliteracy Latinas. Prev Med 39: 99-110, 2004.

148. Cohen M and Azaiza F: Increasing breast examinations among arab women using a tailored culture-based intervention. Behav Med 36: 92-99, 2010.

149. Jibaja-Weiss ML, Volk RJ, Kingery P, Smith QW and Holcomb JD: Tailored messages for breast and cervical cancer screening of low-income and minority women using medical records data. Patient Educ Couns 50: 123-132, 2003.

150. Navarro AM, Senn KL, McNicholas LJ, Kaplan RM, Roppé B and Campo MC: Por La Vida model intervention enhances use of cancer screening tests among Latinas. Am J Prev Med 15: 32-41, 1998

151. Remennick L: 'I have no time for potential troubles': Russian immigrant women and breast cancer screening in Israel. J Immigr Health 5: 153-163, 2003.

152. Berg WA, Blume JD, Adams AM, Jong RA, Barr RG, Lehrer DE, Pisano ED, Evans WP III, Mahoney MC, Hovanessian Larsen L, et al: Reasons women at elevated risk of breast cancer refuse breast MR imaging screening: ACRIN 6666. Radiology 254: 79-87, 2010

153. Yu J, Park A, Morris E, Liberman L, Borgen PI and King TA MRI screening in a clinic population with a family history of breast cancer. Ann Surg Oncol 15: 452-461, 2008.
154. Robson M: Breast cancer surveillance in women with hereditary risk due to BRCA1 or BRCA2 mutations. Clin Breast Cancer 5 260-268, discussion 269-271, 2004.

155. Begley JK, Redpath TW, Bolan PJ and Gilbert FJ: In vivo proton magnetic resonance spectroscopy of breast cancer: A review of the literature. Breast Cancer Res 14: 207, 2012.

156. Belkić K and Belkić D: Possibilities for improved early breast cancer detection by Padé-optimized magnetic resonance spectroscopy. Isr Med Assoc J 13: 236-243, 2011.

157. Katz-Brull R, Lavin PT and Lenkinski RE: Clinical utility of proton magnetic resonance spectroscopy in characterizing breast lesions. J Natl Cancer Inst 94: 1197-1203, 2002.

158. Sardanelli F, Fausto A and Podo F: MR spectroscopy of the breast. Radiol Med (Torino) 113: 56-64, 2008.

159. Tse GM, Yeung DK, King AD, Cheung HS and Yang WT: In vivo proton magnetic resonance spectroscopy of breast lesions: An update. Breast Cancer Res Treat 104: 249-255, 2007.

160. O'Flynn EA, Wilson RM, Allen SD, Locke I, Scurr E and deSouza NM: Diffusion-weighted imaging of the high-risk breast: Apparent diffusion coefficient values and their relationship to breast density. J Magn Reson Imaging 39: 805-811, 2014

161. Eyal E, Shapiro-Feinberg M, Furman-Haran E, Grobgeld D, Golan T, Itzchak Y, Catane R, Papa M and Degani H: Parametric diffusion tensor imaging of the breast. Invest Radiol 47: 284-291, 2012.

162. Allgood PC, Warwick J, Warren RML, Day NE and Duffy SW: A case-control study of the impact of the East Anglian breast screening programme on breast cancer mortality. Br J Cancer 98: 206-209, 2008.

163. Anttila A, Koskela J and Hakama M: Programme sensitivity and effectiveness of mammography service screening in Helsinki, Finland. J Med Screen 9: 153-158, 2002.

164. Duffy SW, Tabár L, Chen HH, Holmqvist M, Yen MF, Abdsalah S, Epstein B, Frodis E, Ljungberg E, Hedborg-Melander C, et al: The impact of organized mammography service screening on breast carcinoma mortality in seven Swedish counties. Cancer 95: 458-469, 2002.

165. Gabe R, Tryggvadóttir L, Sigfússon BF, Olafsdóttir GH, Sigurđsson K and Duffy SW: A case-control study to estimate the impact of the Icelandic population-based mammography screening program on breast cancer death. Acta Radiol 48: 948-955, 2007.

166. Morimoto T, Nagao T, Okazaki K, Kira M, Nakagawa Y and Tangoku A: Current status of breast cancer screening in the world. Breast Cancer 16: 2-9, 2009.

167. Sarkeala T, Anttila A, Saarenmaa I and Hakama M: Validity of process indicators of screening for breast cancer to predict mortality reduction. J Med Screen 12: 33-37, 2005.

168. Vahabi M: Breast cancer and screening information needs and preferred communication medium among Iranian immigrant women in Toronto. Health Soc Care Community 19: 626-635, 2011.

169. www.unlabs.se/mammografi.

170. Domingo L, Sala M, Servitja S, Corominas JM, Ferrer F, Martínez J, Macià F, Quintana MJ, Albanell J and Castells X: Phenotypic characterization and risk factors for interval breast cancers in a population-based breast cancer screening program in Barcelona, Spain. Cancer Causes Control 21: 1155-1164, 2010.

171. Vanags A, Štrumfa I, Gardovskis A, Borošenko V, Aboliņ̌̌ A, Teibe U, Trofimovičs G, Miklaševičs E and Gardovskis J: Population screening for hereditary and familial cancer syndromes in Valka district of Latvia. Hered Cancer Clin Pract 8: 8,2010

172. Venturini E, Losio C, Panizza P, Rodighiero MG, Fedele I, Tacchini S, Schiani E, Ravelli S, Cristel G, Panzeri MM, et al: Tailored breast cancer screening program with microdose mammography, US, and MR Imaging: Short-term results of a pilot study in 40-49-year-old women. Radiology 268: 347-355, 2013.

173. Obralić N and Bešlija $S$ : How to make the best use of limited resources in breast cancer treatment - experiences in Bosnia \& Herzegovina. J BUON 11: 21-29, 2006.

174. Council of the European Union: Council conclusions on reducing the burden of cancer. Employment, Social Policy, Health and Consumer Affairs Council Meeting, Luxembourg, June 10, 2008 . 